\title{
Explaining Anglo-Saxon military efficiency: the landscape of mobilisation
}

\author{
John Baker and Stuart Brookes
}

The importance of warfare in Anglo-Saxon England is widely accepted, but the processes by which armies were put in the field are only partially understood, with most discussion focusing on the economic logistics rather than the spatial practicalities of mobilisation. Yet such a system underpinned recorded military actions and must have evolved in response to changing military organisation in the late Anglo-Saxon period. Through an assessment of documentary references to sites of muster, and by using a multidisciplinary landscape-focused approach, this article examines possible traces of that system - especially those preserved in place-names - and relates them to later Anglo-Saxon administrative geography.

\begin{abstract}
And the Easter after, King Alfred with a small troop built a fortification at Athelney, and from that fortification, with that part of Somerset-men nearest to it, was making war against the raiding-army. Then in the seventh week after Easter he rode to Egbert's Stone to the east of Selwood, and there came to join him all Somerset and Wiltshire and that part of Hampshire which was on this side of the sea-and were glad of him. And one day later he went from those camps to Island Wood [Iglea, or Iley Oak], and one [day] later to Edington, and there fought against the whole raiding-army, and put it to flight, and rode after it as far as the fortification, and stayed there 14 days; and then the raiding-army granted him prime hostages and great oaths that they would leave his kingdom, and also promised him that their king would receive baptism; and they fulfilled it thus. ${ }^{1}$
\end{abstract}

The Anglo-Saxon Chronicle's description of Alfred's mobilisation prior to the Battle of Edington in 878 provides important insights into the mechanisms by which armies of ninthcentury Wessex came together. It is, above all, one of the very few written records for the existence of pre-arranged mustering sites in Anglo-Saxon England. ${ }^{2}$ It is worth noting that these locations were well enough known that they could be used by troops travelling from more than $80 \mathrm{~km}$ away; they were also presumably distinctively marked in the landscapeperhaps monumentalised as the name Egbert's Stone suggests - to allow their identification locally. It is also implicit from this account that mobilisation relied on efficient systems of intelligence and communication. Information about when and where to muster was managed to such a degree that Alfred only needed to stay one day at Egbert's Stone; any provision made for latecomers had a tight timeframe, since Alfred went into battle just two days after arriving there. A further implication is that mustering sites were located on significant longdistance routes, accessible, in this instance, to troops from three shires, and appropriate for the massed forward movement of the armies to engage the enemy. According to this text, such musters were apparently connected to the cadre of fighting units: the shires. Finally, it is clear that the encounter with the Vikings was carefully coordinated. Alfred's staged movement northwards, and the Great Army's advance from Chippenham culminating in their encounter at Edington could only have been achieved either by bilateral agreement or at the very least very careful observation (leading to ambush) of one army already intent on aggression by another that was keen to fight. Presumably because of the difficulties in assembling and maintaining the coherence of armies, pitched battles on open ground are extremely rare in the sources. The detail of the account in the Chronicle makes clear that this was a carefully orchestrated encounter.

\footnotetext{
${ }^{1}$ Anglo-Saxon Chronicle, MS. A, s.a. 878: M. Swanton, The Anglo-Saxon Chronicle (London, 1996), p. 76. 2 J. Peddie, Alfred Warrior King (Stroud, 1999), pp. 134-5; R. Lavelle, 'Geographies of Power in the AngloSaxon Chronicle: the Royal Estates of Anglo-Saxon Wessex', Reading the Anglo-Saxon Chronicle: Language, Literature, History, ed. A. Jorgensen (Turnhout, 2010), pp. 187-219, at 204-7.
} 
The above observations suggest that, whilst the mobilisation of Egbert's Stone may have been exceptional, the system on which it relied was not. Moreover, although references to the assembling of troops in Anglo-Saxon England may on the whole be rare, several others can be identified. Bede mentions a mustering at Wilfaræsdun in 644 in preparation for a battle that never took place, ${ }^{3}$ while Aylesford (1016), Beverston (1051) and Langtree (1051) are all named as such in the Chronicle. ${ }^{4}$ The meeting at Swinbeorg, mentioned in Alfred's will, may also be relevant if, as suggested by Marren, it was the site of a muster prior to the battle of Ashdown in $871 .^{5}$

However rare explicit references to mustering sites may be, working systems of mobilisation are implicit in our understanding of Anglo-Saxon military organisation and underpin many of the events recorded in the Anglo-Saxon Chronicle and other narrative sources. The narrative of Æthelmund's attack on Wessex in 802, for example, which was met before the Hwiccan force could advance beyond the Thames, highlights the speed with which an effective local militia (in this instance the Wilsǣte) could be assembled, even during an interregnum. ${ }^{6}$

The conduct of all warfare, as von Clausewitz makes clear, is predicated by the assembly of forces in time and space. ${ }^{7}$ The nature of such assembly would, however, largely depend upon the kinds of armies being raised, the form of the conflict, and the systems by which troops were levied. All three of these areas underwent significant changes during the period, with the later ninth and early tenth centuries in particular marking a point of considerable innovation in military strategy in conjunction with an escalation of warfare. These changes

\footnotetext{
${ }^{3}$ Bede, Historia ecclesiastica gentis Anglorum, iii. 14: Bede's Ecclesiastical History of the English People, ed. B. Colgrave and R.A.B. Mynors (Oxford, 1969), pp. 256-7.

${ }^{4}$ Several of these are also discussed by A. Pantos, 'Assembly-Places in the Anglo-Saxon Period: Aspects of Form and Location', 3 vols., unpubl. DPhil thesis (Univ. of Oxford, 2002) I, pp. 94-5. Sites of grand diplomacy such as Yttingaford are not discussed here, although of course they may have been similar types of place.

${ }^{5}$ ASC MS. A, s.a. 871, with Asser, Vita Alfredi, ch. 35, in S. Keynes and M. Lapidge, Alfred the Great: Asser's Life of King Alfred and Other Contemporary Sources (Harmondsworth, 1983), pp. 174 and 315 n. 9. See also P. Marren, Battles of the Dark Ages: British battlefields AD 410 to 1065 (Barnsley, 2006), p. 13. As Keynes and Lapidge point out, the battle presumably took place in 870 or early 871 , a period of frequent engagements between the West Saxons and Viking invaders; so the probability that the Swinbeorg assembly acted as a muster prior to battle is high.

${ }^{6}$ Athelweard, Chronicon, iii. 3: The Chronicle of AEthelweard, ed. A. Campbell (London, 1962), pp. $27-8$. Speed of reaction and the sustainability under pressure of systems of mobilisation seem specifically to be emphasised in the narrative accounts of the events of 870-1 (ASC A, s.a. 871; Keynes and Lapidge, p. 78). Within three days of the arrival of the vikings at Reading, Ethelwulf was able to assemble a force from Berkshire capable of defeating them at Englefield. It should be noted that many important Berkshire centres such as Lambourn, Wantage, Kintbury and Faringdon were $20 \mathrm{~km}$ or $30 \mathrm{~km}$ away from the site of the battle - no more than a day's march in good conditions (see, e.g., F.M. Stenton, 'The Road System of Medieval England', EconHR 7 (1936), 1-21, at 16, reptd in Preparatory to Anglo-Saxon England, ed. D. Stenton (Oxford, 1970), pp. 235-52, at 247-9). R. Lavelle, Alfred's Wars (Woodbridge, 2010), pp. 191-3 and Table 5.2, helpfully sets out probable average speeds for different elements of an army, some of which were mounted, but makes the point that 'if 20 miles $(31.2 \mathrm{~km})$ was a long day's march, 10 miles $(16.1 \mathrm{~km})$ may be reckoned to be the maximum distance after which a force could still be expected to be in condition to fight after travelling'. Since the battle of Englefield took place in December (M.L.R. Beavan, 'The Beginning of the Year in the Alfredian Chronicle (866-87)', EHR 33 (1918), 328-42, at 334), conditions may not have been good. Such a response represents no small logistical achievement and it is notable that the Danes were contained in the Reading area for several months, perhaps a result of the rapid West Saxon response.

${ }^{7}$ C. von Clausewitz, On War, trans. J.J. Graham (London, 1997), Book III, chpt xi-xii, pp. 175-82. The central importance of mobilisation and military logistics in early medieval contexts has been recently discussed by, among others, J.F. Haldon, 'Introduction. Why model logistical systems?', in General Issues in the Study of Medieval Logistics, ed._J. F. Haldon (Leiden, 2006), pp. 1-36; and G. Halsall, Warfare and Society in the Barbarian West (London, 2003), pp. 40-162.
} 
will have impacted on the requirements and logistics of manpower, and, therefore, on systems of mobilisation.

A first key distinction can be drawn between forces assembled for offensive and defensive campaigns. $^{8}$ It has long been argued that during the early and middle Anglo-Saxon period the former consisted essentially of elite warriors-what Hollister conveniently labelled the 'select fyrd' of kings, the king's landed dependants, and other land-owning lords, along with their household followers - which in the Anglo-Saxon Chronicle are always described by their geo-political affiliation (i.e. West Saxon, Mercian, etc.). ${ }^{9}$ These can be contrasted with defensive forces, which narrative accounts suggest were of regional identity and ad hoc mobilisation. ${ }^{10}$ Examples of this type include West Saxon responses to armed invasions in the ninth century which seem to have been based on shire units (the Wilsǣte in 802, Sumors̄̄te and Dornsǣte in 848, the men of Hampshire and Berkshire in 860); often led by the local ealdorman; and assembled for a specific task (a single battle or rapid succession of battles). The precise composition of these armies is much debated, but the assumption-encapsulated most clearly in Hollister's concept of the 'great fyrd' - is that these consisted of much larger forces, drawing (in addition to the select fyrd) on militias of freemen. ${ }^{11}$ The shire levy, as Powicke points out (and as Alfred's Laws make clear), was not only the first point of reference in policing local disturbances, but a basic unit from which larger defensive forces could be constructed. ${ }^{12}$ If the shire was one of the systems through which armies were raised, it is clear that developments in the eighth and early ninth centuries more closely linked together landowning and military service. It is at this time - certainly in Mercia, and probably in Kent - that charters with clauses reserving military obligations provide the first evidence of more systematic military structures being in place. ${ }^{13}$ These formalised, on the one hand, the nature of levies and the obligations imposed on the land-owning sections of society, and, on the other, the physical infrastructure of military authority. Against this backdrop it is easy to envisage the operation of two parallel systems of mobilisation, defined according to their defensive or offensive purpose. Aggressive campaigns, with forces often led by kings and

\footnotetext{
${ }^{8}$ This distinction is drawn particularly by T. Reuter, 'The Recruitment of Armies in the Early Middle Ages: What can we Know?', in Military Aspects of Scandinavian Society in a European Perspective, AD 1-1300, ed. A. N. Jørgensen and B. L. Clausen (Copenhagen, 1997), pp. 32-7, at 34, and G. Williams, 'Military Institutions and Royal Power', Mercia: an Anglo-Saxon Kingdom in Europe, ed. M. P. Brown and C. A. Farr (Leicester, 2001), pp. 210-29.

${ }^{9}$ C.W. Hollister, Anglo-Saxon Military Institutions (Oxford, 1962). The case for pre-Viking warfare as an aristocratic occupation has been advanced particularly by H. M. Chadwick, The Origins of the English Nation (Cambridge, 1907); E. John, Orbis Britanniae (Leicester, 1966), pp. 128-53; R. Abels, Lordship and Military Obligation in Anglo-Saxon England (Berkeley, 1988), pp. 11-42. Hollister's concept of the 'select' and 'great' fyrd is critiqued by, amongst others, N. Hooper, 'Anglo-Saxon Warfare on the Eve of the Conquest: a Brief Survey', ANS_1 (1979 for 1978), 84-93, at 87-8; Abels, Lordship, pp. 4-5; Lavelle, Alfred's Wars, pp. 68-70.

${ }^{10}$ Ninth-century descriptions of the armies of the sixth to eighth centuries may conform to later Anglo-Saxon preconceptions, but those of the late eighth and ninth centuries would have been assembled within the living memory of, or at only a few removes from, the writers of late ninth-century texts.

${ }^{11}$ On this, and the subsequent point, it is significant to note that unlike recent historical writing, which has downplayed the role in civil defence assigned to the common citizenry (e.g. John, Orbis, pp. 132-46; Abels, Lordship, pp. 60-2; Halsall, Warfare and Society, pp. 86-7; Lavelle, Alfred's Wars, pp. 98-106; cf. N. P. Brooks, rev. of Halsall, Warfare and Society in the Barbarian West, in EHR 120 (2005), 424-6, at 245, and Reuter, 'Recruitment of Armies', pp. 34-5), the view from archaeology - exemplified most recently by A. Reynolds, 'Archaeological Correlates for Anglo-Saxon Military Activity in Comparative Perspective', Landscapes of Defence in the Viking Age, ed. J. Baker, S. Brookes and A. Reynolds, Studies in the Early Middle Ages 28 (Turnhout, 2013) - is of wide-spread and significant militarisation across early medieval society. ${ }^{12}$ M. Powicke, Military Obligation in Medieval England: a Study in Liberty and Duty (Oxford, 1962), pp. 1316.

${ }^{13}$ N. Brooks, 'The Development of Military Obligations in Eighth- and Ninth-Century England', England Before the Conquest: Studies in Primary Sources presented to Dorothy Whitelock, ed. P. Clemoes and K. Hughes (Cambridge, 1971), pp. 69-84.
} 
consisting primarily of warrior elites, which by their nature permitted a greater level of planning and logistical support, are likely to have used networks of royal and aristocratic landholding in order to mobilise. ${ }^{14}$ By contrast, emergency defensive operations, which drew upon a wider population beyond the warrior elite, would have been more closely tied to existing civil structures with predetermined mustering places. ${ }^{15}$

On the other hand, there is no reason why the personnel of offensive or defensive forces should have differed significantly in terms of socio-economic status. The actual fighting force in each case may well have consisted of the same thegnly cohort; but a campaigning army is unlikely to have been operational without the support of a significant non-combatant contingent. ${ }^{16}$ Crucial differences can be assumed in the size of the forces mobilised (including both armed and unarmed participants) and, more importantly, in the processes of mobilisation involved. In the first case, numerical variance would be a natural corollary of the raising of forces from a national pool on the one hand, and a single shire on the other (even if somewhat counterbalanced by a more selective mobilisation nationally than was expedient locally under emergency conditions). Differences in the processes of mobilisation would follow not only from this, but also from the different requirements of the carefully-planned constitution of an expeditionary force for a long, external campaign, and the rapid mustering of troops to confront an immediate, possibly unpredicted and temporary territorial threat.

Places of assembly were important not only from the perspective of efficient mobilisation, but also from that of strategy more generally. Certainly, efficiency in response to threats depended on intimate knowledge of the communications infrastructure. It may also have been due in part to a system of early warning - there is clear evidence for the existence of lookouts across southern Britain. ${ }^{17}$ However, neither of these would have been of much use without a well-choreographed process of mobilisation, allowing troops to be raised and manoeuvred into the required position in sufficient numbers and at adequate speed, without simultaneously being kept in the field longer than their motivation or provisions permitted. ${ }^{18}$ This concern would have been acute even for armies made up only of eligible members of the weapons-carrying elite. In some analyses, shire militias depended on the mobilisation of as many able-bodied freemen as possible in the areas nearest to the perceived threat,

\footnotetext{
${ }^{14}$ Lavelle, Alfred's Wars, p. 99, stresses that it was important for such forces to eat and drink well, thereby emphasizing the logistical demands associated with campaigning of this kind. Penda's army of 655, which reputedly consisted of 30 duces regii (Bede, HE iii. 24, ed Colgrave and Mynors, pp. 290-1 and note 2) may be an expression of this kind of force. Later examples include Egbert's campaigns of 825-6 and Æthelred and Alfred's expedition to Nottingham in 868.

${ }^{15}$ ASC 878; Peddie, Alfred Warrior King, pp. 134-5; Marren, Battles of the Dark Ages, p. 13. John's comments (Orbis, pp. 147-53) on this point are important to remember, namely that this local infrastructure of assembly could also intersect with that of elites of varying statuses.

${ }^{16}$ A good attempt to calculate the size of this force is provided by J. Haldon, 'Introduction. Why model logistical systems?', in General Issues in the Study of Medieval Logistics, ed. J. Haldon (Leiden, 2006), pp. 136, at 1-18. See also M. Blackburn, 'The Viking Winter Camp at Torksey, 872-3', Viking Coinage and Currency in the British Isles, ed. M. Blackburn (London, 2011), pp. 221-64.

${ }^{17}$ D. H. Hill and S. Sharp, 'An Anglo-Saxon Beacon System', Names, Places and People: an Onomastic Miscellany in Memory of John McNeal Dodgson, ed. A. R. Rumble and A. D. Mills (Stamford,1997), pp. 15765; G. Gower, 'A Suggested Anglo-Saxon Signaling System between Chichester and London', London Archaeologist 10 (2002), 59-63; Lavelle, Alfred's Wars, p. 174; J. Baker, 'Warriors and Watchmen: Placenames and Anglo-Saxon Civil Defence', MA 55 (2011), 258-67, at 261-4; J. Baker and S. Brookes, Beyond the Burghal Hidage (Leiden, 2013), pp. 179-99.

${ }^{18}$ Halsall, Warfare and Society, pp. 127 and 156-7. These logistical concerns would also have influenced the locations of battlefields themselves, which for these reasons may often have been linked in some way to well established assembly sites. The location and spatial characteristics of early medieval battle sites may reward further analysis, but are excluded from the present discussion as they are the subject of PhD research currently being undertaken by Tom Williams at the UCL Institute of Archaeology under the supervision of Andrew Reynolds and Stuart Brookes.
} 
representing, therefore, a serious temporary drain on agricultural manpower. This too would have limited the time a force could be kept in the field and increased the importance of rapid mobilisation and clearly defined responses.

Alfred's reforms, recounted in the Chronicle entry for 891, can be seen as an attempt to enhance the role and effectiveness of central authority in these mobilisations. The division of the fyrd into two 'so that always half of its men were at home, half on service, apart from the men who guarded the boroughs, ${ }^{19}$ though ultimately designed to provide for greater continuity in military actions, also required more persistent supervision and administration. The rotation of troops stationed in strongholds with those on a tour of duty could not have been achieved without advanced administrative efficiency, and nor could the logistical concerns of supplying simultaneously stationary garrisons and mobile forces. Further administrative complications can also be surmised regarding the raising of armies, and the methods of calculating duty and its cash equivalent. ${ }^{20}$ Since the final local muster in any such mobilisation was presumably the burh, ${ }^{21}$ these reforms may over time have replaced the preeminent shire or multiple-shire mustering points, such as Egbert's Stone, in practical importance. Mustering within a burh removed some of the dangers of fragmentation, providing supplies, security and spatial coherence to the mustered force.

Whether discussing the composition of armies and their military goals, the territorial basis of military service, or the logistical concerns of mustering, campaigning, and battle, the crucial geographical framework for the bringing together of forces - the landscape of mobilisation - is often overlooked in studies of Anglo-Saxon militarism. While the processes may be obvious - the gathering of troops at pre-arranged mustering sites - the sites themselves have much more to reveal about the composition and structure of early medieval armies. This paper makes use of landscape evidence to advance our knowledge of AngloSaxon mobilisation beyond the limits of narrative, administrative and fiscal sources. It considers the link between known assembly places and systems of muster, and suggests a number of other sites at which military gatherings may have taken place. Furthermore, it argues that changes in the organisation of armies over the course of the later Anglo-Saxon period would have had an impact on the mechanisms that permitted military obligations to be carried out, and this impact is likely to be detectable in the organisation of the landscape of mobilisation.

\section{The hundredal system and mobilisation}

In late Anglo-Saxon England, one highly organised system that regularly brought large numbers of people together is very clearly attested - the network of hundreds into which each shire was divided for administrative purposes. In all likelihood, places of legal or

\footnotetext{
${ }^{19}$ ASC A 891; see also Asser, Vita Alfredi, chs. 99-102

${ }^{20}$ In one of the most detailed discussions of this relationship between land tenure and military service, Hollister Anglo-Saxon Military Institutions, pp. 38-58, has drawn particular attention to the emergence by the eleventh century of the 'five-hide unit': a rule of recruitment visible in most of the shires of southern England, by which every five hides of land produced one warrior for military expeditions. However, the five-hide unit was a fiscal as well as a military assessment; in the absence of a suitable warrior-representative, service could be valued at the equivalent rate of $2 s$ on the hide (ibid. p. 48).

${ }^{21}$ E.g. ASC A 917; Lavelle, Alfred's Wars, p. 256. This interpretation casts a different light on the events of 1006 (ASC 1006 CDE). Cuckhamsley Knob (Cwicelmeshlawe) fulfils all of the criteria described below for a here-hlāw mustering point. The failure of the vikings to provoke a response from the English by occupying this location might simply signify that this shire-level system had already been superseded by that of burghal mobilisation, at least in Wessex, depriving Cwicelmeshlaewe of its military functions (though not necessarily its legal and administrative ones); the vikings were perhaps standing on the wrong spot! We have used the term 'burh' in normal type and treated it as a part of modern vocabulary, rather than an Old English term, in order to reflect its use as a normal part of modern archaeological and historical discourse. We recognize that OE fyrd and here sometimes fall into the same category; here they are given in Italics to avoid confusion with modern English 'here'.
} 
governmental assembly were an integral part of the Anglo-Saxon system of mobilisation, and indeed several of the musters recorded in the Chronicle have been identified as the centres of Domesday administrative districts. ${ }^{22}$ That this system of judicial governance intersected to some degree with that of mobilisation would hardly be surprising: as the socially ingrained sites of regular mass gatherings, sites of judicial or governmental assembly - the meetingplaces of hundreds, wapentakes, lathes and so on-would have formed a reliable basis for military musters; indeed, it might be considered that that is precisely what they originally were, since many of those attending such assemblies belonged to the weapons-bearing sections of society. Moreover, as military recruitment was assessed locally on units of landholding, it is probable that mustering - whether for campaigning or to review the completeness and order of troops under arms - required mechanisms which were closely related to those of taxation, administration, and punishment in the localities. The principal institution fulfilling these roles, at least by the mid-tenth century, appears to have been the hundred. How clearly these apparently separate functions were differentiated in early times, or where the original emphasis of such meetings lay, are difficult questions to answer, but some underlying military function can be discerned. ${ }^{23}$ Ealdorman Æthelweard, writing in the later tenth century, seems to endow the term 'hundred' (centurias) with military characteristics. $^{24}$

The hundredal system as it appears in Domesday is superficially irregular and had apparently already undergone several phases of modification by the later eleventh century; but the archetypal system that underlies it was clearly both highly regular and tightly regulated. Legislation decreed that hundred meetings should be held every four weeks and that all freemen should attend. ${ }^{25}$ Even the name of the administrative units, which notionally consisted of 100 hides each (whether or not they did in practice), suggests regularity and, perhaps, top-down imposition, at least in parts of England (and perhaps following a

\footnotetext{
${ }^{22}$ Iley Oak is thought to have been the meeting-place of Warminster and Heytesbury hundreds, whose courts met at Ilegh in 1439 (O.S. Anderson, The South-Western Counties, pp. 150-1; J.E.B. Gover, A. Mawer and F.M. Stenton, The Place-Names of Wiltshire, EPNS 16 (Cambridge, 1939), 154-5; A. Pantos, 'AssemblyPlaces', I, 94-5); Aylesford gives its name to one of the Kentish Lathes and may therefore have been its meeting-place (J. K. Wallenberg, The Place-Names of Kent (Uppsala, 1934), pp. 99 and 145; O.S. Anderson, The South-Eastern Counties, p. 115); and Langtree is identified with Longtree, one of the Gloucestershire hundreds (Anderson, The South-Western Counties, pp. 26-7; A. H. Smith, The Place-Names of Gloucestershire, pt 1, EPNS 38 (Cambridge, 1964), 85; Pantos, 'Assembly-Places'). Swinbeorg is more controversial. It is sometimes identified with Swanborough Tump, the probable meeting-place of the Wiltshire hundred of Swanborough, but early forms call this identification into doubt (English Historical Documents, c.500-1042, ed. D. Whitelock, 2nd ed., English Historical Documents 1 (London, 1979), 534, n. 1; Gover et al., Place-Names of Wiltshire, pp. 317, 320).

${ }^{23}$ E. John, 'The Age of Edgar', in The Anglo-Saxons, ed. J. Campbell (Oxford, 1982), pp. 160-91; J. Campbell, 'The Late Anglo-Saxon State: a Maximum View', PBA 87 (1995), 39-65; and see below.

${ }^{24}$ Ethelweard Chronicon iii. 3 (ed. Campbell, p. 28); John, 'Age of Edgar', pp. 160-91, at 172; Campbell, 'Late Anglo-Saxon State', pp. 59-60. Lavelle, Alfred's Wars, p. 101, has also discussed William of Malmesbury's reference to the organization of Alfred's kingdom into hundreds [hundrez] and tithings [tithingas] (William of Malmesbury, 'Gesta Regum Anglorum / The History of the English Kings' I, ed. R. A. B. Mynors with R. M. Thomson and M. Winterbottom (Oxford, 1998), p. 188), and their possible association with royal military followers. It is also worth noting that the term wapentake, used in the Danelaw for divisions equivalent to the hundred, is from ON vápnatak 'taking or touching of weapons', which suggests that those who gathered there were expected to be bearing arms (A. H. Smith, English Place-Name Elements, pt II [JAFN-YTRI], EPNS 26 (Cambridge, 1956), 229; H. Kurath, et al., Middle English Dictionary (Ann Arbor, MI, 1956-2001), s.n. wäpentāke).

${ }^{25}$ E.g. III Edmund, ch. 2, Hundred Ordinance, and II Cnut, ch. 20, in Die Gesetze der Angelsachsen I, ed. F. Liebermann (Halle, 1903), 190-5 and 322; discussed by (among others) H. M. Chadwick, Studies on AngloSaxon Institutions (Cambridge, 1905), pp. 239-48, and H. R. Loyn, The Governance of Anglo-Saxon England 500-1087 (London, 1984), pp. 140-6.
} 
continental exemplar). ${ }^{26}$ A connection might be made between this and other very regular elements of the late Anglo-Saxon military administrative system - the five-hide unit of military and fiscal assessment, the three-hundred hide ship-soke, shires (at least in parts of England) apparently arranged in a geographically regular way around a burh, and so on. ${ }^{27}$

The hundredal system should also be seen within the context of recruitment to the army, for by the late ninth century this too was very regular. Under Alfred, to reiterate, West Saxon human resources were divided into three parts - those who garrisoned the burhs, those who served in the fyrd and those who tended the land - and importantly, the fyrd was always in service. This could be achieved in more than one way, and perhaps the staffing of these shifts involved massive periodic changes in personnel - this is certainly implied by the Chronicle's comment that the fyrd besieging Hæsten at Thorney had completed its tour of duty (hie hæfdon stemn gesetenne) before Alfred could arrive with a replacement force. ${ }^{28}$

Nevertheless, regularised military service would be harder to manage if the manner and frequency of musters and the numbers of troops mobilised varied too much from district to district. ${ }^{29}$ It is tempting therefore to posit the establishment of a relatively regularly structured system of multi-functional moots/military musters more or less contemporaneously with and supplementary to a similarly regular system of fortification and military organisation. As Molyneaux notes, it may not be a coincidence that we first hear of the hundreds during the tenth century. ${ }^{30}$

Even if we accept that the hundredal system, and the meeting-places of those administrative districts, formed the basis for an efficient and regular system of mobilisation in late Anglo-Saxon England, a number of important gaps remain in our understanding of the landscape of mobilisation. It is very hard to be sure if any of the district assembly-sites fossilised in the Domesday record go back beyond the late Anglo-Saxon period, and since most of the musters mentioned in the narrative sources date from the age of Alfred or later, pre-Alfredian sites of muster are more or less invisible in documentary terms. Yet kings had been emphasising the central importance of public assembly at least since the seventh century, ${ }^{31}$ and reserving military obligations since the mid-eighth, ${ }^{32}$ so the centrality of public assembly at a much earlier period is strongly hinted at, and we know that warfare and the

\footnotetext{
${ }^{26}$ H. Adams, 'The Anglo-Saxon Courts of Law', in H. Adams, et al., Essays in Anglo-Saxon Law (Boston, MA, 1876), pp. 1-54, at 20-1; H. M. Cam, Local Government in Francia and England (London, 1912), pp. 27 and 59-61; P. Wormald, 'Papers Preparatory to The Making of English Law: King Alfred to the Twelfth Century, II: From God's Law to Common Law', ed. S. Baxter and J. Hudson (2014), published online at the 'earlyenglishlaws' website, pp. 196-7.

${ }^{27}$ E.g. J. H. Round, Feudal England (London, 1895), pp. 44-69; C. Hart, The Hidation of Cambridgeshire (Leicester, 1974), pp. 12-14; Hollister, Anglo-Saxon Military Institutions, pp. 38-58 and 108-12; Stenton, Anglo-Saxon England, pp. 336-7; S. Bassett, 'The Administrative Landscape of the Diocese of Worcester in the Tenth Century', St Oswald of Worcester: Life and Influence, ed. N. Brooks and C. Cubitt (Leicester, 1996), pp. 147-73.

${ }^{28}$ OE text quoted from Two of the Saxon Chronicles Parallel, I: Text, Appendices and Glossary, ed. C. Plummer (Oxford, 1892), s.a.

${ }^{29}$ A more efficient system is easy to imagine, and would involve almost continual and regular replacement of troops, so that the coherence of the army was maintained even as the personnel changed; in other words, a system of mobilisation that almost precisely reflects the regularity that the hundredal system provided.

${ }^{30}$ G. Molyneaux, 'Why were Some Tenth-Century English Kings Presented as Rulers of Britain?', TRHS 21 (2011), 59-91. It may also be significant that the system of districts actually called hundreds extended only as far as the midlands in any systematic way, and beyond that gave way to wapentakes; it might only have been in southern England that late Anglo-Saxon kings were able to levy forces in this regular and systematic fashion.

${ }^{31}$ Ethelberht, ch. 1, and Hlothhere and Eadric, ch. 8, in Laws of the Earliest English Kings, ed. F. L. Attenborough (Cambridge, 1922).

${ }^{32}$ P. H. Sawyer, Anglo-Saxon Charters: an Annotated List and Bibliography (London, 1968), no. 92. This catalogue, available online in a revised and updated form at www.esawyer.org.uk, is cited hereafter as $\mathrm{S}$, followed by the number of the charter.
} 
exercise of military authority were integral parts of society in the early and middle AngloSaxon periods. It seems very likely, therefore, that elements of the hundredal system were in place from an early period - existing perhaps within a very different administrative framework - and that at least some of their functions were military. Establishing which sites formed the basis of mobilisation prior to the Alfredian and later reforms is of considerable potential importance for our understanding of the equivalent arrangements in, say, Mercia and Wessex.

It is worth noting, moreover, that later Anglo-Saxon tactical units at the level of the shire, burh, and ship-soke may also have required identifiable places of assembly. The origins of these groupings are somewhat unclear, ${ }^{33}$ but it is likely that developments in military organisation were accompanied by changes in the organisation and the landscape setting of musters. A careful, landscape-based approach may be able not only to demonstrate the existence of pre-hundredal elements of a system of mobilisation, but also to throw light on the potentially hierarchical nature of later Anglo-Saxon arrangements.

\section{The landscape and language of mobilisation}

A landscape approach may be able to supplement our knowledge and understanding of this important aspect of Anglo-Saxon warfare. Here we meet with an immediate difficulty, for sites of occasional temporary use are unlikely to leave a marked and easily identifiable imprint in the archaeological record. ${ }^{34}$ Topographically, it is easier to define likely contexts for military gatherings than actually to identify sites of muster themselves. For example, major gatherings of this type - shire or multiple-shire musters of the Egbert's Stone type-are likely to have been easy to access, perhaps from more than one district or shire, and wellmarked on the ground, so proximity to important route-ways, centrality to areas of settlement, and the presence of a defining natural or man-made feature should be anticipated. Whether or not Anglo-Saxon military mustering has left anything other than the most ephemeral of physical imprints, the recurrent gathering of large groups of armed men, and the specialised function of the sites at which they came together are likely on occasion to have left a longstanding mark in local toponymy, above and beyond the names of mustering sites discussed above, and a consideration of certain types of place-name may therefore provide a means of identifying some of the sites at which musters were held.

The names of the small number of recorded mustering sites noted above are worth consideration. Ecgbrihtesstan, Beverston, Aylesford, Langtree and Swinbeorg have the generics stān 'stone', ford 'ford', trēow 'tree' and beorg 'mound', and of the Domesday hundreds named after their meeting-places, almost two thirds are named after stones, mounds, trees or river crossings. ${ }^{35}$ The names of most of these mustering sites conform in one

\footnotetext{
${ }^{33}$ Indeed, these districts are likely to have originated at different times: the main shires of Wessex make their appearance in the sources during the eighth and ninth centuries, burhs during the ninth century, and hundreds and perhaps the ship-sokes in the second half of the tenth century: The Wiley Blackwell Encycloedia of AngloSaxon England, ed. M. Lapidge, et al., 2nd ed. (London, 2014), pp. 249 and 434-5; Loyn, Governance, pp. 140-1. The origins of the hundred are discussed in further detail by, amongst others: H.R. Loyn, 'The Hundred in England in the Tenth and Early Eleventh Century,' British Government and Administration: Studies Presented to S.B. Chrimes, ed. H. Hearder and H. R. Loyn (Cardiff, 1974), pp. 1-15; P. Warner, 'Pre-Conquest Territorial and Administrative Organization in East Suffolk,' Anglo-Saxon Settlements, ed. D. Hooke (Oxford, 1988), pp. 9-34; M. Gelling, The West Midlands in the early Middle Ages (Leicester, 1992), pp. 141-5; B. Yorke, Wessex in the Early Middle Ages (Leicester, 1995), pp. 123-32; and see further below.

${ }^{34}$ Methods pioneered by the UCL Landscapes of Governance project have set out an agenda for the desk-top and field-based assessment of such sites. See J. Baker and S. Brookes, 'Identifying Outdoor Assembly Sites in Early Medieval England', Jnl of Field Archaeol. 40, pt 1 (2015), 3-21; S. Brookes and J. Baker, 'A Checklist for Identifying Early Medieval Meeting-Places', www.ucl.ac.uk/archaeology/research/projects/ assembly/Checklist

${ }^{35}$ More than $3 \%$ contain the generic dūn of Wilfarasdun. The data for these calculations can be found in O. S. Anderson, English Hundred-Names: the South-Eastern Counties, Lunds Universitets Arsskrift 37.1 (Lund,
} 
way or another with the types of compound regularly associated with the meeting-places of late Anglo-Saxon administrative districts. Their first elements, on the other hand, less clearly belong to a single type. Personal names dominate (if that can be said of such a small corpus), forming the first elements of Aylesford, Ecgbrihtesstan, Wilfaræsdun and perhaps Beverston, and although some of those names might have resonated with historical or mythical significance-Egbert was an important ancestor of Alfred and Ægel was a figure from Germanic legend - others did not, or at least not obviously, and the significance of such first elements is difficult to assess. ${ }^{36}$

This corpus might be supplemented by examining place-name terminology descriptive of military activity, and in particular the Old English (OE) element here. The main meaning of here is 'an army', and although a more general application to 'a multitude of people' seems to have developed, the sense 'army' is shared by its Germanic cognates and must be treated as primary. ${ }^{37}$ Although OE here is well represented in place-names, it is striking that very few hundreds or their identified meeting-places have names of this kind. ${ }^{38}$ The possibility that the hundredal system intersects with a system of mobilisation is discussed above, yet the toponymic evidence for military activity at such sites is only slight. Among a class of sites whose principal function was the bringing together of significant bands, it may not appear surprising that names indicating the assembling of an army did not seem very distinctive; but

1939), especially pp. 192-208), and by reference to individual entries in this and the other two volumes of Anderson's survey: English Hundred-Names, Lunds Universitets Arsskrift 30.1 (Lund, 1934) and English Hundred-Names: The South-Western Counties, Lunds Universitets Arsskrift 35.5 (Lund, 1939).

${ }^{36}$ J. Baker, 'Meeting in the Shadow of Heroes? Personal Names and the Socio-Political Background of Assembly Places', in Power and Place in Later Roman and Early Medieval Europe, ed. J. Carroll, A. Reynolds and B. Yorke (forthcoming). Etymological discussion of these names and Iglea can be found in Smith, PlaceNames of Gloucestershire, pt 1, p. 85 (Langtree); A. H. Smith, The Place-Names of Gloucestershire, pt 2, EPNS 39 (Cambridge, 1964), p. 213 (Beverston); Anderson, The South-Eastern Counties, p. 115, and Wallenberg, Place-Names of Kent, pp. 99 and 145 (Aylesford); Anderson, South-Western Counties, pp. 150-1; Gover, Mawer and Stenton, Place-Names of Wiltshire, pp. 154-5 (Iglea). Ecgbrihtesstan, Swinbeorg and Wilfarcesdun are transparently 'Egbert's stone', 'pig mound' and 'Wilfhere's hill' respectively.

${ }^{37}$ See An Anglo-Saxon Dictionary Based on the Manuscript Collections of the Late Joseph Bosworth, ed. T. N. Toller (Oxford, 1898), with Supplement (Oxford, 1921), at p. 532 and cf. p. 534 s.n. hergian 'to harry', and Supplement, p. 537; J. Pokorny, Indogermanisches Etymologisches Wörterbuch (Bern, 1959), pp. 615-16; J. Wright, Grammar of the Gothic Language, 2nd ed. (Oxford, 1954), p. 326 (s.n._ON herr 'army'). In placenames, Smith takes here to denote 'an army'; see A. H. Smith, English Place-Name Elements, pt 1 [Á-ĪW], EPNS 25 (Cambridge, 1956), 244.

${ }^{38}$ It should be noted at the outset that compounds involving generics denoting roads and tracks - here-pað, péod-weg, fyrd-strāt_and so on - are omitted from this survey. As has been argued elsewhere (J. Baker, 'The Language of Anglo-Saxon Defence', Landscapes of Defence in Early Medieval Europe: Anglo-Saxon England and Comparative Perspectives, ed. J. Baker, S. Brookes and A. Reynolds (Turnhout, 2013), pp. 65-90), some of these roads may have arisen by association with places of muster, but there could be a number of other reasons for which such road-names were coined. In any case, they were route-ways rather than possible focal places. The compound OE here-beorg is also omitted. The second element is not OE beorg 'hill, mound' (which would parallel OE $h l \bar{a} w$ in here-hlāw, discussed below) but a formally similar term related to OE gebeorg 'protection', beorgan 'to protect, defend' (A Dictionary of Old English, ed. A. diP. Healey, et al. (Toronto, 1986-), s.v.). The compound does not therefore denote a landmark at which a host might gather, but a place where a host might take refuge: 'shelter or protection for a number of men, army quarters' (Smith, Elements, pt 1, 244; cf. OE herebeorgian 'to shelter'), or 'harbour, shelter, lodgings, quarters' (Anglo-Saxon Dictionary, ed. Toller, p. 538). The sense 'shelter' is also evidenced in Germanic cognates OHG heri-berga, OIcel herbergi (E. Förstemann, Altdeutschesnamenbuch 1 (Bonn, 1913), p. 1247, sub Hariberg; Smith, Elements, pt 1, 244). ME herberze, herborouz meant 'a shelter (for travellers), a lodging, an inn', and is apparently often found, especially in southern England, in the sense 'lodging, inn' (ibid.), a sense also apparent in Icelandic her-bergi 'an inn' (G. Vigfusson, An Icelandic-English Dictionary (Oxford, 1874), p. 257). Since the element is not confidently identified in any English place-name before 1100, it seems doubtful that it has any relevance to the present discussion. 
place-name references to judicial activity and debate - other obvious functions of these sites-are relatively common by comparison. ${ }^{39}$

OE here is particularly well represented in three recurrent place-name compounds (Figure 1): OE here-hlāw 'army mound', here-feld 'army open land', and here-ford 'army ford'. ${ }^{40}$ These compounds are found in a considerable number of place-names, and this suggests that they constituted functional labels - the language of administrators, attached to place-names and later fossilised as place-names proper (analogous with OE $\underline{\text { àc-tūn }}$ or burh-tūn $)^{41}$ —rather than ad hoc toponymic formations in the language of local inhabitants. Although these compounds containing OE here, have often evaded clear explanation, ${ }^{42}$ it is worth noting that their generics, OE hlāw, feld and ford, are well represented in the names of Domesday hundreds and their meeting-places. ${ }^{43}$ Of about 800 hundred- and wapentake-names, 33 bear the generic hlāw, 19 the generic feld and 40 ford. ${ }^{44}$ In other words, although this group of lexical compounds may not be found very frequently in the names of hundreds themselves, they clearly share in the language of assembly. The complete lack of similar types of compound in OE folc or mægð (both of which mean 'folk, people' and both of which occur in place-names and compound nouns) is also telling. It suggests, for these compounds, the active choice of a word denoting a fighting force rather than simply a large body of people. ${ }^{45}$

There has been little discussion of here-hlāw as a recurrent compound. Ekwall took the first element of Harlow (Essex) to mean 'the whole people', perhaps principally because this was also the name of a Domesday hundred; ${ }^{46}$ but the lack of any close correlation between Harlow names as a group and known hundred meeting-places, and the general rarity of hundred-names denoting multitudes of people, seem to count against this explanation. ${ }^{47}$

\footnotetext{
${ }^{39}$ J. Baker, 'The Toponymy of Communal Activity: Anglo-Saxon Assembly Sites and their Functions', Els noms en la vida quotidiana. Actes del XXIV Congrés Internacional d'ICOS sobre Ciències Onomàstiques. Annex. Secció 7, ed. J. Tort I Donada, published online (2014, pdf format), at www.gencat.cat/llengua/ BTPL/ICOS2011/cercador.html, pp. 1494-1509, at 1496-7.

${ }^{40}$ For convenience, detailed discussion of the material has been placed in an appendix.

${ }^{41}$ See M. Gelling, The Place-Names of Shropshire, pt 1 (Nottingham, 1990), 1-9 and 38-41.

${ }^{42}$ The problem is twofold. Does here in such place-names refer, specifically or figuratively, to an actual army or to a large group of people? Is the sense literal - 'frequented by an army or a large group of people'; metaphorical - 'suitable for an army or large group of people'; administrative - 'maintained by the nation or army'; or general - 'public, used by or associated with everyone'. It might even be suggested that names of this kind record a particularly famous event involving an army or large group of people - a battle perhaps (cf. e.g. Reynolds 'Archaeological Correlates' on the origins of Englefield; G. Jones, 'Penda's Footprint? Place-Names Containing Personal Names Associated with those of Early Mercian Kings', Nomina 21 (1998), 29-62). In fact, named Anglo-Saxon battlefields are rarely of this type (Tom Williams, pers. comm.). The second issue, addressed below, is that of the particular status of the hlāw, feld or ford qualified by the word here.

${ }^{43}$ Anderson, English Hundred-Names, pp. xxxiii-xxxvii; A. Pantos, 'The Location and Form of Anglo-Saxon Assembly-Places: Some "Moot Points", Assembly Places and Practices, ed. Pantos and Semple, pp. 155-80, at $156-7$.

${ }^{44}$ It is hard to assess the true significance of these figures in the absence of a rigorous statistical analysis of all Domesday place-names - they may be entirely in keeping with the corpus as a whole (M. Gelling ('On Looking into Smith's Elements', Nomina 5 (1981), 39-45, at 39), for instance, notes c. 200 examples of feld place-names and c. 550 ford names in the whole of Ekwall's Concise Oxford Dictionary, cited below). However, at least 130 of the hundred-names are known to belong to the chief manors of the hundreds concerned, and not necessarily to their meeting-places. Of these, none have the generic hlāw, while feld and ford occur only 3 and 4 times respectively. Though only a guide, this suggests that the occurrence of feld in hundred-names could simply be a function of its common occurrence in Domesday place-names, while the other elements are more likely to occur as meeting-place elements.

${ }^{45}$ Smith, Elements, pt 1, 179; Smith, Elements, pt 2, 32.

${ }^{46}$ E. Ekwall, The Concise Oxford Dictionary of English Place-Names, 4th ed. (Oxford, 1960), s.n. and under OE here.

${ }^{47}$ On the first of these objections, see below; on the second, see Baker, 'Toponymy of Communal Activity', p. 1497.
} 
Discussion of OE here-feld 'army open land', which survives in a small number of placenames, sums up the problems of interpretation. In their survey of Middlesex place-names, Gover, Stenton and Mawer decided that it was 'impossible to say at what particular period the name [Harefield] may have arisen or just what its significance may be', ${ }^{48}$ and in the final edition of his dictionary, Ekwall still felt that 'the meaning of such a name is not apparent', although he raised the idea of assembly of some kind. ${ }^{49}$ Mills suggested that the 'army' signified by the element here was perhaps a Viking army, ${ }^{50}$ probably because Alfredian narrative sources distinguish between the Anglo-Saxon fyrd and the Viking here; but this is far from convincing, not least on grounds of distribution, and Watts says that the 'reason for the name is unknown'. ${ }^{51}$

OE here-ford is another traditionally troublesome compound in toponymic discussion, but the corpus is fairly well established. Attempts to explain the compound have proved difficult. Stenton and Mawer provided a translation without further comment: 'army ford'. ${ }^{52}$ Ekwall took here-ford to denote a ford 'where a marching column could pass in closed order', ${ }^{53}$ a sense closely echoed by Mills, ${ }^{54}$ but Torvell dismissed any military relevance in most of the place-names, pointing out that at least one of the fords (Torvell's identification of the likely ford at Harford, Devon) could never have been appropriate for the crossing of an army. $\mathrm{He}$ felt also that such names could not be the commemoration of single famous military campaigns, which might be expected to produce more specific names such as 'Hengist's ford' or similar. Instead, in Torvell's analysis, a here-ford was more likely to have been a river crossing of regional importance, specifically maintained by the local inhabitants, so that it was passable all year round, either because it was on a route of major economic importance, or because other routes would become treacherous during certain seasons, forcing travellers to pass by the here-ford. However, this explanation also requires a certain amount of special pleading regarding the economic significance of the fords and route-ways so-named and of their settlements, given the small number of surviving examples.

Alternatively, there may be some connection with the construction here-pæð-ford, found at least nine times in place-names and charter boundaries: five times in Devon, twice in Somerset, and once each in Oxfordshire and Surrey; but here-ford is unlikely to be a reduced form of the triple compound. While it is clear that here-pæð-ford names tend to undergo reduction over time, a reflex of the middle syllable is generally still evident until fairly lateup to the present time in modern forms such as Hartford and Harpford, and into the fourteenth century at least in the case of Harford in Devon. ${ }^{55}$ The survival of Domesday and pre-Domesday forms for the here-ford names requires such a reduction to have occurred at a very early stage. On the other hand, here-ford might be elliptical for here-pæð-ford, where here has become spoken shorthand for here-pæð. ${ }^{56}$ The distributions of here-ford and herepæð-ford overlap, in as much as the latter is found concentrated in southern England, between Hartford in Devon and the remaining here-ford names which are north of the Thames. However, the distributions are essentially different, raising the possibility of a regional variation. Nevertheless, this solution is problematic and Carroll and Parsons consider it to be

\footnotetext{
${ }^{48}$ J. E. B. Gover, A. Mawer and F. M. Stenton, The Place-Names of Middlesex, EPNS 18 (Cambridge, 1942), p. 35 .

${ }^{49}$ Ekwall, Concise Oxford Dictionary, s.n. and sub OE here.

${ }^{50}$ A. D. Mills, Oxford Dictionary of British Place-Names (Oxford, 2003), s.n.

${ }^{51}$ V. Watts, The Cambridge Dictionary of English Place-Names (Cambridge, 2004), s.n.

${ }^{52}$ Stenton and Mawer, Place-Names of Bedfordshire and Huntingdonshire, p. 208

${ }^{53}$ Ekwall, Concise Oxford Dictionary.

${ }^{54}$ Mills, Oxford Dictionary, s.n.

${ }_{55}^{5}$ J. E. B. Gover, A. Mawer and F. M. Stenton, The Place-Names of Devon, 2 vols., EPNS 8-9 (Cambridge, 1931-2), 342

${ }^{56}$ Ekwall, Concise Oxford Dictionary, s.n. Hereford; Watts, Cambridge Dictionary, s.n. Hereford.
} 
uncertain. ${ }^{57}$ Since the same compound occurs in continental toponymy, ${ }^{58}$ it might be necessary to posit parallel early developments of here-pæð-ford and an elliptical here-ford across the West Germanic language region, and this seems an unsatisfactorily convoluted means of explaining the compound.

The possibility that here-ford might refer to a site at which large gatherings took place does away with any need for the fords in question to be communication routes of national importance, or for the roads on which they lie to be of here-pæd type or to be major longdistance route-ways of any kind. A here-ford, even as a place of military muster, would not need to be situated on a defensive alignment. We might expect places of muster to be in or close to strategically important zones, but not necessarily in positions of strength. A ford marking a site of assembly need not be a major ford (and indeed frequently is not), since it only needs to mark the point on the road where the meeting is going to take place - as long as it is distinctive enough to serve that purpose, and providing its surroundings meet any practical requirements, it can be almost insignificant as a crossing point or infrastructural hub. Finally, a mustering- or meeting-place might well occur on a major route-way, but could just as easily be on a smaller road linking other elements of the transport network. ${ }^{59}$

The interpretation of here- names proposed here removes a major stumbling block in the understanding of the names as a class. If they are functional appellative compounds, there is little need for the landscape features to which they are attached to share precisely the same physical characteristics; it is their role in the organisation of society that unites them, and therefore their wider landscape is perhaps more significant than their immediate topographical form. Given that the primary sense of OE here is 'army', the most natural interpretation of these three compounds is as sites where armed groups gathered periodically. That such sites might also have held other administrative functions is quite possible, but would not diminish the force of this argument.

\section{The topography}

A select corpus of place-names with forms likely to represent OE here-hlāw, here-feld or here-ford, and related compounds, is set out in the Appendix. These names belong to an administrative language of assembly, and make specific reference to armed groups. Their topographical locations suggest that they also form part of a landscape of assembly. Many of the sites display one or more of a range of features shared with known assembly places: proximity to important route-ways; association with boundaries of some significance; affiliation with monumental sites or places of early ceremonial importance (which may in some cases predate administrative arrangements of the later Anglo-Saxon period). Moreover, several instances of the compounds discussed above have a spatial relationship to assembly sites identified from other evidence.

The only here-hlāw place-name with pre-Conquest forms is Harlow in Essex (1), ${ }^{60}$ which gave its name to Harlow half hundred, so its credentials as a meeting-place are reasonably secure. $^{61}$ The meeting-place of the hundred is thought to have been an earthwork mound $\underline{c}$.

\footnotetext{
${ }^{57}$ J. Carroll and D. Parsons, Anglo-Saxon Mint-Names, I: Axbridge-Hythe (Nottingham, 2007), at 162.

${ }^{58}$ W. T. Beetstra, Toponimen en toponimyske elemintenyn Fryslân: in analytyske bibliografy ca. 1835-1980 (Leeuwarden, 1987), p. 75; D. Berger, Geographische Namen in Deutschland (Mannheim,1993), s.n. Herford. ${ }^{59}$ The ford at which the hundred of Uttlesford (Essex) met, now marked by Uttlesford Bridge, was probably a minor river-crossing by a major road; that of Holeford hundred (Gloucestershire) was distinctive, but probably not significant; and Barford (Bedfordshire) met at the crossing of a major river, but not on an obviously important early long-distance route-way.

${ }^{60}$ Numbers in brackets refer to the list of here- names in the Appendix.

${ }^{61}$ Christy, Gelling, and Watts take the name to refer to the small hill west of the railway station, on which a Romano-Celtic temple stood, but Ekwall is surely right in taking the name to refer to the hundred meeting-place, which is focused on a still-visible mound. The element hlāw normally denotes artificial mounds in southern counties, and Gelling explains the posited reference to the natural hill of Harlow temple on the basis that part of
} 
$25 \mathrm{~m}$ in diameter and $1.5 \mathrm{~m}$ high located on the edge of Mulberry Green. ${ }^{62}$ This was Mudborow, Mudbrowne Grene in the seventeenth century and Moteberghe in 1382, later reflexes of OE (ge)mōt-beorg 'assembly mound' ${ }^{63}$ This name may only have arisen after the place-name Harlow had become semantically opaque, and it certainly emphasises the tradition of gatherings on the site. Perhaps indicative of this function, the mound has a slightly flattened summit of $\underline{\mathrm{c}}$. $8 \mathrm{~m}$ diameter; a feature common to purpose-built assembly mounds in England and Scandinavia. ${ }^{64}$

There is no known record of assembly at Harlow in Staffordshire (9), but the place lies in Mayfield parish. ${ }^{65}$ This has been derived from the plant-name madder with OE $\underline{\text { feld }},{ }^{66}$ but Duignan and Horovitz suggest an alternative first element OE mæðel 'meeting, council', ${ }^{67}$ which certainly seems to explain some of the forms more satisfactorily. ${ }^{68}$ Harville (Kent) is in Wye parish, located approximately $1 \mathrm{~km}$ west of the centre of Wye, the head not only of a Kentish hundred, but of the Domesday lathe of that name. ${ }^{69}$ Given this association it is likely that meetings of hundred and lathe took place close to the settlement and therefore very close to Harville. Few other sites discussed here produce such clear evidence of communal gatherings, but a tradition of assembly might be assumed at Hereford (14), which became the centre of a shire, while Hartford (17) is just $2 \mathrm{~km}$ north-east of Huntingdon, another shire caput and a late Anglo-Saxon burh. The meeting-place of Elthorne Hundred, the district in which Harefield (10) is located, has not been satisfactorily identified $;^{70}$ it is not impossible that the thorn-bush alluded to in the name was situated somewhere in the here-feld. The

this hill had been artificially scarped; but the presence of another, wholly man-made mound provides a more convincing alternative. See M. Christy, 'The Essex hundred-moots: an attempt to identify their meeting-places', Trans. of the Essex Archaeol. Soc., ns 18 (1928), 172-97, at 190-1; M. Gelling, Signposts to the Past, 3rd ed. (Chichester, 1997), p. 135; Watts, Cambridge Dictionary, s.n.; Ekwall, Concise Oxford Dictionary, s.n.

${ }^{62}$ Reaney, The Place-Names of Essex, EPNS 12 (Cambridge, 1935), p. 37; Anderson, South-Eastern Counties, pp. 38-9.

${ }^{63}$ cf. Gover et al., Place-Names of Devon, p. 279, for the change of Mot- to Mod-

${ }^{64}$ A. R. Adkins and M. R. Petchey, 'Secklow Hundred Mound and Other Meeting-Place Mounds in England', ArchJ 141 (1984), 243-51. The identification of flat-topped mounds as meeting-places/cult sites is common to both Scandinavia and Ireland, and has been adopted - by analogy - also in British archaeology. In Sweden, the lower flat-topped mound at Gamla Uppsala "was still used as a meeting place up to the eighteenth century, and is known as the Thing or Assembly mound" (H. Ellis Davidson, 'Royal Graves as Religious Symbols', ASSAH 5 (1992), 25-32, at 28). Adam of Bremen, writing in the late eleventh century, makes the connection between this - the lower mound - and the 'temple' explicit: 'the shrine stands on level ground with mountains all about it like a theatre' (History of the Archbishops of Hamburg-Bremen, trans. F.J. Tschan (New York, 1959), IV, 26, Shol. 139, p. 207). In Ireland, flat-topped mounds at, for example, Tara and Clogher, have long been associated with royal assembly (R. Warner, 'Notes on the Inception and Early Development of the Royal Mound in Ireland', Assembly Places and Practices, ed. Pantos and Semple, pp. 27-43, at 32-6). The still functioning meetingmound of Tynwald Hill, Isle of Man, is also flat-topped.

${ }^{65}$ Medevelde 1086, Machelfeld, Malefeld c.1150, Matlefelt c.1175, Methelfeld 1183-4, Matherfeld c.1203

${ }^{66}$ OE mæddre; e.g. Ekwall, Concise Oxford Dictionary, p. 318; Watts, Cambridge Dictionary, p. 404

${ }^{67}$ Duignan, Notes on Staffordshire, pp. 100-1; Horovitz, Place-Names of Staffordshire, s.n.

${ }^{68}$ Horovitz further posits a derivation from OE (ge)mōt 'assembly' and Welsh carn for the first part of nearby Motcarn Sprink (1836), on Ordley Brook about $1 \mathrm{~km}$ west of Middle Mayfield. At this point, another stream joins Ordley Brook, so it could be a reference to a meeting of waterways rather than of people, and it should be noted that the earliest form is too late for any certainty; but it might be significant to the present discussion. See Horovitz, Place-Names of Staffordshire, s.n.

${ }^{69} \mathrm{~S} 1180$ uses the phrase 'on Weowerawealde', the 'weald of the men of Wye', perhaps indicating the existence of the lathe by the eighth century. In Domesday Book it was known as 'Wiwarlet lest'. On the origins of the Kentish lathe of Wye see, in particular, N. Brooks, 'The Creation and Early Structure of the Kingdom of Kent', The Origins of Anglo-Saxon Kingdoms, ed. S. Bassett (Leicester, 1989), pp. 55-74, and S. Brookes, 'The Lathes of Kent: a Review of the Evidence', Studies in Early Anglo-Saxon Art and Archaeology: Papers in Honour of Martin G. Welch, ed. S. Brookes, S. Harrington, S. and A. Reynolds, BAR Brit. Ser. 527 (Oxford, 2011), 15670.

${ }^{70}$ Anderson, South-Western Counties, p. 56; Gover et al., Place-Names of Middlesex, p. 31 
spatial association of about a third of the corpus with Anglo-Saxon meeting-sites attested on historical grounds or through use of independent toponymic evidence is sufficient to suggest that this class of place-name might be connected with assembly in some way. ${ }^{71}$

In common with attested assembly sites, many of the here place-names also show close proximity to elements of the middle- and long-distance transport system of the Anglo-Saxon period. The three Essex Harlows are all on or close to important Roman or prehistoric routes: the Roman road leading to Braughing (Mgy 329) (1), the Icknield Way (3), and the Roman road from Braintree to Bury St Edmunds (Mgy 33a) (7). In fact, Harlow (1) is located at an infrastructural hub, being on the south-east bank of the River Stort, at its meeting with Mgy 329, and also perhaps on an OE here-strǣt, if this is the origin of Hare Street (1777) just to the west in Great Parndon and situated near to the road leading eastwards through Old Harlow. ${ }^{72}$ Harville in Kent is at a similarly impressive intersection of route-ways; it lies close to the crossroads of the Pilgrim's Way and Mgy 130 on the west bank of the River Stour at the point where it is crossed by the Pilgrim's Way. ${ }^{73}$ Hereford (He) (14) lies on the River Wye $1 \mathrm{~km}$ south of Mgy 63a, one of the main Roman roads leading west into Wales; Hartford (Hu) (17) lies on the north bank of the River Great Ouse $1 \mathrm{~km}$ to the east of the major crossing of the river by the Roman roads $\underline{M g y} 22, \underline{M g y} 2 b$, and $\underline{M g y} 24$; and Harraton (Du) (18) at the point where the River Wear is crossed by Mgy 80b.

Strikingly, a number of the sites discussed here occupy geographically liminal positions within important and early administrative divisions, and in some cases are close to linear defensive works. Harlow (1) is not central to the Domesday hundred of that name, but located on its north-west boundary and the Essex border. ${ }^{74}$ Another Harlow place-name in the historic county of Essex also occupies a liminal position. The Heydon example (3) is now in Cambridgeshire, and was always close to the Cambridgeshire, Hertfordshire and Essex borders. Several archaeological monuments emphasise this location as a border region during the early medieval period: partially within the same parish of Heydon lies Bran Ditch, a postRoman linear earthwork of c. $5.6 \mathrm{~km}$, arguably used to define agricultural territories lying between forest and marsh; and this earthwork also served as the location of an execution cemetery during the late ninth to eleventh centuries. ${ }^{75}$ A cluster of here- places in the north of

\footnotetext{
${ }^{71}$ Since this paper was first written, another possible occurrence of OE here-hlāw has come to light. In his reinterpretation of Catholme as a place of assembly, John Blair notes the proximity of a field named Arlow (pers.comm. and J. Blair, 'Exploring Anglo-Saxon settlement', Current Archaeology 291 (June 2014), 12-22, at 17-18; Arlow is so named in 1837, see R. Hardy, A History of the Parish of Tatenhill in the County of Stafford (London, 1907), p. 204). In the absence of earlier spellings, the etymology of this name is difficult to ascertain, but another instance of Harlow, with loss of initial $\underline{\mathrm{H}-}$, is a strong possibility. Its location on the Staffordshire/ Derbyshire boundary is worthy of note.

${ }^{72}$ Reaney, Place-Names of Essex, p. 49. The abbreviation Mgy followed by a number refers to the numbering of roads in I.D. Margary, Roman Roads in Britain, 3rd ed. (London, 1973).

${ }^{73}$ The antiquity of the Pilgrim's Way has recently been demonstrated by archaeological excavations at White Horse Stone, near Boxley in Kent (C. Hayden and E. Stafford, 'The Prehistoric Landscape at White Horse Stone, Boxley, Kent' (unpubl. report, CTRL Integrated Site Report Series, 2006). At this location two (possibly three) trackways were excavated below the Pilgrim's Way, representing predecessors for the later highway between London, Canterbury and the Kent coast. Although all three trackways were of a post-Roman date, closer dating was complicated by poor artefactual evidence. Nevertheless, close to the Pilgrim's Way, and stratigraphically earlier than the youngest predecessor was a Middle Anglo-Saxon crossroad burial (cal AD 680970). This is likely to have been contemporary with the second hollow-way; the first lying directly on the line of the present-day routeway.

${ }^{74}$ This border does not coincide with the limits of the Anglo-Saxon diocese of London, which was perhaps coextensive with the province of the East Saxons; but Harlow would not have been far from the edge of that territory.

${ }^{75}$ The functions of the Cambridgeshire dykes are discussed by, amongst others, L. Alcock, Economy, Society and Warfare among the Britons and Saxons (Cardiff, 1987); T. Malim, 'New Evidence on the Cambridgeshire Dykes and Worsted Street Roman Road', Proc. of the Cambridge Antiq. Soc. 85 (1996), 27-122; J. Wileman,
} 
England can be seen occupying the southern borderlands of Bernicia. Perhaps, the most interesting of these - Harlow Hill (2) - is a distinctive eminence crested by Hadrian's Wall, $23 \mathrm{~km}$ west of Newcastle. The highest point of the hill (at $169 \mathrm{~m}$ O.D.) lies $300 \mathrm{~m}$ north of Milecastle 16; an installation likely to have functioned as a fortified gateway through the monument for a time during the Roman period. ${ }^{76}$

The association between here- places and major shire and regional boundaries is emphasised by several further examples. Harlow in Mayfield (St) (9) lies just 1.2km west of the Domesday border of Staffordshire and Derbyshire. Little Hereford (He) (15) is 300m north of the Herefordshire/Worcestershire boundary, and is only $2.8 \mathrm{~km}$ west of the point where the boundary of those two shires met that of Shropshire. Similarly, Harvington in Worcestershire (13) lies $1 \mathrm{~km}$ south of the boundary with Warwickshire, and $5 \mathrm{~km}$ west of that with Gloucestershire. Finally, Harefield (Mx) (10) lies $1.7 \mathrm{~km}$ away from the three-way intersection of Middlesex, Hertfordshire, and Buckinghamshire.

If these place-names do reflect the existence of mustering points, then the material discussed so far might not be comprehensive. OE here-wīc '(dependent) settlement associated with an army' occurs in at least three place-names in Kent, Essex and Lincolnshire, and there have been suggestions that these might have been military encampments. ${ }^{77}$ The compound is analogous with the attested fyrd-wic, which is very clearly used of military camps. ${ }^{78}$ The coastal location of Harwich in Essex and Harwich Street in Whitstable, Kent, might have been suitable for a naval muster, or a mustering prior to embarkation. Whitstable, it should be noted, was the centre of another Kentish hundred. Together with OE here-ford we should perhaps also examine OE bēod-ford, a compound identified in four East Anglian and Lincolnshire place-names. ${ }^{79}$ Although the military connotations of OE bēod 'a nation, people' or 'a district' are less obvious than for $\mathrm{OE}$ here, ${ }^{80}$ the evocation of the involvement of a large group of people (perhaps a group of people representative of a nation), or of association with an established district, is certainly in keeping with the function of a mustering site. Indeed, a military association has been noted. ${ }^{81}$ Although pēod is taken to mean 'public' in some instances, ${ }^{82}$ and might well have that sense when compounded with generics denoting routeways or features of route-ways, such as fords, it is still necessary to explain the specific significance of such compounds, and to define the ways in which they were considered to be especially 'public'. Since the compound occurs only in one region, and does not apparently

'The Purpose of the Dykes: Understanding the Linear Earthworks of Early Medieval Britain', Landscapes 2 (2003), 59-66. The execution site of Bran Ditch was excavated in the 1920s, and is discussed by A. Reynolds, Anglo-Saxon Deviant Burial Customs (Oxford, 2009) pp. 106-8, with references.

${ }^{76}$ There are no surface remains at or near this spot today and trial trenching in the 1930s failed to identify any archaeological evidence for the milecastle, E. Birley, Research on Hadrian's Wall (Kendal, 1961), p. 96, however, comparison with other excavated sites, and the rigidly regular spacing of milecastles along Hadrian's Wall argue for it having once existed. Excavations of milecastles have demonstrated that their functions as gateways were re-evaluated during the mid- to late second century, with a number of milecastle-gates falling out of use following the construction of the Antonine Wall, whilst others saw significant enhancements during the third and fourth centuries, H. G. Welfare, 'Causeways, at Milecastles across the Ditch of Hadrian's Wall', Archaeologia Aeliana, 5th ser. 28 (2000), 13-25, at 18. The lack of archaeological evidence from Milecastle 16 strongly suggests that the former situation applies here.

${ }^{77}$ J. K. Wallenberg, Kentish Place-Names (Uppsala, 1931), pp. 216-17; Reaney, Place-Names of Essex, p. 339; K. Cameron, in collaboration with J. Field and J. Insley, The Place-Names of Lincolnshire, pt 3, EPNS 66 (Nottingham, 1992), 51; R. Coates, 'New Light from Old Wicks: the Progeny of Latin vicus', Nomina 22 (1999), 75-116, at 105.

${ }^{78}$ Dictionary of Old English, ed. Healey, et al., s.v.

${ }^{79}$ See appendix.

${ }^{80}$ Bosworth and Toller, Anglo-Saxon Dictionary, p. 1048.

${ }^{81}$ J. Roberts and C. Kay, with L. Grundy, A Thesaurus of Old English, 2 vols. (London, 1995) I, 610, at $\$ 13.02 .10 .01 .02 .01 .01$

${ }^{82}$ Smith, Elements, pt 2, 203. 
overlap with the semantically comparable here-ford, it might be proposed that the two compounds denote similar sites. It is worth noting that Thetford in Norfolk was a hundred meeting-place situated on the boundary between Norfolk and Suffolk, at the crossing of the Little Ouse by the Icknield Way and at the convergence of two important Roman roads: Mgy 333 and Mgy $332 .{ }^{83}$

Perhaps surprisingly, OE fyrd 'army (service), military expedition', the term frequently used in narrative sources to describe the West Saxon and Anglo-Saxon armies of the ninth and tenth centuries, is relatively rare in place-names, found most often in compound with generics referring to roads, and never apparently in compound with hlāw, ford or feld. ${ }^{84}$ Three instances with other generics are worth noting: Verdley in Sussex (Verdelay 1318), where the second element is OE lēah 'woodland' and an (ealden) fyrdgeat mentioned in the bounds of two separate Anglo-Saxon charters, for Headborne Worthy and Micheldever in Hampshire, ${ }^{85}$ but probably referring to a single feature. ${ }^{86}$ As Mawer et al. note Verdley may have 'taken its name from some long forgotten hosting'. ${ }^{87}$ In the second instance we have a compound of OE fyrd and geat 'gap, gate', with OE ald added in one instance, hence 'the (old) army gate'. As many as seven hundreds seem to have met at places with names in geat, suggesting that gates were somehow appropriate markers for meeting-places. ${ }^{88}$ If Grundy's identification is correct, the site is close to the Winchester to Andover Roman road, and it is worth noting that Micheldever was a villa regalis. The third instance is the fyrdhammas in a charter for Stanmore, Berkshire. ${ }^{89}$ The second element is clearly OE hamm (pl hammas), but there is uncertainty surrounding the first. Gelling took it to be OE fyrde a variant of ford, hence 'ford meadows', but acknowledged that this variant was not otherwise found as a first element. Others have taken the first element to be OE fyrd, ${ }^{90}$ in which case the compound might mean 'army enclosures', and Forsberg posited a mustering-place for the Berkshire fyrd, though preferring to explain fyrd in this and the previous instance as ellipsis for fyrd-strǣt or fyrd-wīc, hence 'enclosures by the fyrd-strǣt'. The only known compounds of fyrd with strǣt or other words meaning 'road' are located in the midlands, ${ }^{91}$ while here-pæð is well-evidenced in Berkshire, so it seems unlikely that an elliptical reference to a fyrd-strǣt should occur in this area.

Whether or not peod and fyrd place-names are included, the material discussed above clearly raises a number of questions; two are particularly important. Firstly, does the geographical positioning of the sites have significance, both in terms of their individual

\footnotetext{
${ }^{83}$ Watts, Cambridge Dictionary, s.n.

${ }^{84} \mathrm{cf}$. Baker, 'The Language of Anglo-Saxon Defence', pp. 75-84. Wuerdle near Rochdale, Lancashire (de Werdull c.1180) is taken by E. Ekwall, The Place-Names of Lancashire (Manchester, 1922), p. 57, to be a compound of $\mathrm{OE}$ weorod 'troop, host' and hyll 'hill', and may therefore be relevant.

${ }^{85}$ S 309 (Old Minster, Winchester), dated 854; and S 374 (New Minster, Winchester), dated 904. It should be noted that the former is spurious in its received form; S 374 is 'acceptable', according to S. Miller (ed.), Charters of the New Minster, Winchester (Oxford, 2001), p. 43.

${ }^{86}$ G. B. Grundy, 'The Saxon Land Charters of Hampshire with Notes on Place and Field Names. 3rd Series', ArchJ 83 (1926), 91-253, at 128-9; G. B. Grundy, 'The Saxon Land Charters of Hampshire with Notes on Place and Field Names', ArchJ 84 (1927), 160-340, at 309.

${ }^{87}$ A. Mawer, F. M. Stenton and J. E. B. Gover, The Place-Names of Sussex, 2 vols., EPNS 6-7 (Cambridge, 1929-30), I, 20.

${ }^{88}$ J. Baker and S. Brookes, 'Gateways, Gates, and Gatu: Liminal Spaces at the Centre of Things', Neue Studien zur Sachsenforschung (in press).

${ }^{89} 948\left(13^{\text {th }}\right)$ S 542 (a 'probably authentic' charter, although the date was perhaps miscopied, S, Kelly (ed.), Charters of Abingdon Abbey, 2 vols (Oxford, 2000-2001), vol.1, p. 174).

${ }^{90}$ e.g. R. Forsberg, 'An Edition of the Anglo-Saxon Charter Boundaries of Berkshire', SN 51 (1979), 139-51, at 150-1; Charters of Abingdon Abbey, pt 1, ed. S. E. Kelly, AS Charters 7 (Oxford, 2000), at 175.

${ }^{91}$ Baker, 'The Language of Anglo-Saxon Defence'.
} 
landscape settings and of their overall distributions? Do these allow us any level of confidence concerning the original function of the sites? The etymological background of the place-names is certainly in favour of reference to military activities and specifically to the mustering of armies, but such an interpretation requires external support. Secondly, if these are mustering sites, when were they in use as such? This question may be fundamental to understanding the origins and structure of Anglo-Saxon administrative districts, the hierarchical relationship between different types of meeting- or mustering-place, and the workings of mobilisation, and should perhaps be discussed first.

\section{Dating of here names}

It is notoriously difficult to deduce dates for the first coining of individual place-names. Usually it is possible only to state a date by which the name was in use, which is the same date as its first record. On that basis we cannot push the date of any here name discussed here far back into the Anglo-Saxon period. Harvington is recorded in charters purportedly dating to 709,799 (for 802?) and $963-4,{ }^{92}$ but none of these survives in a manuscript copied earlier than the eleventh century and all are of disputed authenticity. On the other hand, the names in question could have been formed decades or centuries before their first surviving attestation. The absence from early texts (especially from narrative ones) of a class of compounds that makes reference to large groups of people, whatever their reason for gathering, is perhaps unexpected given the many references to events that would have involved major gatheringsgrand diplomacy, synods and battles-but not entirely surprising if compounds such as herehlāw were functional appellatives rather than organic place-names. ${ }^{93}$

Another possible clue to the dating of this class of place-names can be taken from their generics. While a number of them are compounded with $\mathrm{OE}$ ford, a similar compound in $\mathrm{OE}$ brycg is extremely rare. ${ }^{94}$ The latter element could mean 'causeway' as well as 'bridge' and so need not belong to a period of advanced bridge technology, but it is worth noting that properly maintained bridges do not seem to have become a widespread feature of AngloSaxon England before the middle of the tenth century. ${ }^{95}$ While ford is the generic in 40 English hundred- and wapentake-names, brycg occurs 18 times and is therefore a significant generic for districts or their meeting-places. Some of these may have originated as ford names, becoming brycg names only when a bridge replaced the ford, so there is no need to assume that they are part of a late group of meeting-places; but the relative absence of

\footnotetext{
${ }^{92} \mathrm{~S} 80$ (an apparently spurious charter from Evesham, in a twelfth- or thirteenth-century manuscript), S 154 (from Worcester, probably authentic, but with a question over its date; the earliest surviving copy is in an early eleventh-century manuscript, but an incomplete seventeenth-century copy of the lost original also survives), $\mathrm{S}$ 731 (a twelfth-century forgery, also from Worcester).

${ }^{93}$ B. Cox, 'The Place-Names of the Earliest English Records', JEPNS 8 (1976), 12-66.

${ }^{94}$ Herbychemare (Oxfordshire) is a possibility, see M. Gelling, The Place-Names of Oxfordshire, 2 vols., EPNS 23-4 (Cambridge, 1953-4), I, 227.

${ }^{95}$ A. Cooper, Bridges, Law and Power in Medieval England, 700-1400 (Woodbridge, 2006), pp. 8-15; D. Harrison, 'Bridges and Communications in Pre-Industrial England', unpubl. DPhil thesis, Univ. of Oxford (1996), p. 234. A more generous opinion of Anglo-Saxon bridge-building is given in D. Harrison, The Bridges of Medieval England: Transport and Society 400-1800 (Oxford, 2004), pp. 100-5; indeed, archaeological evidence suggests substantial causeways were built already in the eighth century, such as the 'The Strood' linking the island of Mersea to the Essex mainland, which has been dated by dendrochronology to A.D. $693 \pm$ 9.40 (P. Crummy, J. Hillam and C. Crossan, 'Mersea Island: the Anglo-Saxon Causeway', Essex Archaeol. and Hist. 14 (1982), pp. 77-86); a timber bridge over the Trent at Cromwell (Nt), presumably forming a spur road linking up with the Foss Way (C. Salisbury, 'An 8th-century Mercian bridge over the Trent at Cromwell, Nottinghamshire, England', Antiquity 69 (1995), 1015-18; and the 'Grandpont' at Oxford, for which see Oxford Before the University, ed. A. Dodd (Oxford, 2003), pp. 53-6. To this list can probably also be added the reinstated Roman bridge over the Medway at Rochester, N. Brooks 'Rochester Bridge, AD 43-1381', Communities and Warfare 700-1400, N. Brooks, 219-265, at p. 250.
} 
references to bridges among here names may indicate that they were long-fossilized placenames by the time bridges were commonplace (and perhaps by the time bridges replaced the crossings they named).

OE here-ford, here-feld and pēod-ford all have exact continental parallels in Herford (Hervord 1290), Nordrhein-Westfalen, Germany, ${ }^{96}$ Herveld ( Gelderland, Netherlands, ${ }^{97}$ Dietfurt a.d. Altmühl, Bayern, Germany, and Dietfurt, Kanton St Gallen, Switzerland. ${ }^{98}$ What this tells us about the chronology of such compounds is unclear. It is perhaps suggestive of a shared language community, which would be consistent with an early date - but most of the examples are found in areas where branches of West Germanic very close to English were spoken, and where similar compounds might have evolved collectively or independently. The elements in question remained active lexical items on the continent and in England throughout the period. ${ }^{99}$

It may also be significant that fyrd is so rarely found in this type of compound. There are no known instances of *fyrd-hlāw, *fyrd-ford or *fyrd-feld, although of course the compounds fyrd-strǣt and fyrd-weg do occur, and the present survey has only uncovered two or three reliable instances of fyrd in compound with elements that do not refer to route-ways. Old English fyrd seems to be unique among its Germanic cognates in its semantic evolution. The root meaning of Proto-Germanic * fartiz is likely to have been something like 'journey', and this sense is apparent in most branches of the Germanic language group. ${ }^{100}$ Only in Old English does this root sense seem to have developed into '(military) expedition', 'military service' and ultimately '(expeditionary) military force'.

Elements cognate with fyrd are found occasionally in continental place-names, but with connotations of travel or movement. For example, Vaartbroek near Eindhoven in NoordBrabant, the Netherlands (Vaart Broek 1837) is taken to be a reference to 'navigable marshland', ${ }^{101}$ and Förstmann renders $\mathrm{OHG}$ fart, OFris ferd in place-names as 'iter, via'. ${ }^{102}$ Of course, English place-names containing fyrd might have the same sense, but this seems unlikely if compounds such as fyrd-weg are taken into account, since it would give a meaning 'journey/expedition road' - in other words a semantically superfluous specific. Indeed, this sense is not recorded in Old English texts (DOE sub fyrd) and may therefore have become obsolete at an early stage and certainly by the late ninth century boom in literary output. If fyrd place-names can be taken alongside here names, then the period at which the names were coined might have coincided with the period at which fyrd began to develop its attested Old English meaning 'army', which it certainly had by the late ninth century, but when such a use was still relatively restricted. This would explain why fyrd names are much less common than those with the specific here. It is important to reiterate that fyrd is used in English toponymy, including sometimes in appellative compounds, and almost certainly with the

\footnotetext{
${ }^{96}$ Förstemann, Altdeutschesnamenbuch, 1248-9; Berger, Geographische Namen, p. 132.

${ }^{97}$ Förstemann, Altdeutschesnamenbuch, 1248; G. van Berkel and K. Samplonius, Nederlandse Plaatsnamen (Utrecht, 1995), p. 94.

${ }_{98}$ Berger, Geographische Namen, p. 77.

${ }^{99}$ It seems likely that OE mæel, possibly the first element of Mayfield near Harlow, Staffordshire, became obsolete in Old English at an early date (Pantos, "Assembly Places', p. 45; Pantos, "In medle oððe an pinge": the Old English Vocabulary of Assembly', Assembly Places and Practices in Medieval Europe, ed. A. Pantos and S. Semple (Dublin, 2004), pp. 194-5). This suggests that Mayfield was the site of assemblies from an early date, although its implication for nearby Harlow is not clear, since the latter name may have been coined at a later date in recognition of continued use of the area for important gatherings.

${ }^{100}$ E.g. OFris ferd, OSax fard, OHG fart, ModGer Fahrt 'journey'; OIcel ferd 'journey, (personal) conduct'; and various verbal cognates $\overline{\mathrm{OE}}$ faran, Gothic faran, fōr, farjan, OIcel fara, ferja, OHG ferien, ferren, with senses related to 'travel'; J. Porkorny, Indogermanisches Etymologisches Wörterbuch, I (Bern, 1959), 816-17; OED sub ferd, $\mathrm{n}$.

$\frac{101}{10}$ van Berkel and Samplonius, Nederlandse Plaatsnamen, p. 237.

${ }^{102}$ Förstemann, Altdeutschesnamenbuch, pp. 854-5 s.n. fard.
} 
sense 'army'; but that its use in that context is rare. ${ }^{103}$ Even if some fyrd place-names are given an entirely different explanation, it would not undermine the rest of the argument set out here; and the question would remain: why, once fyrd had come to mean 'military force', and when it was an active place-name element with that sense, was it not used to coin placenames in the same way as here was? The choice of here in such compounds, to the exclusion of fyrd, would probably have much the same implications for the dating of here- placenames. On balance, a period around the later eighth and early ninth centuries might seem reasonable on linguistic grounds for the coining of most of these here names, the reservations already expressed notwithstanding.

\section{Geographical distributions}

In discussing the location of here- place-names, it is clear that there is meaningful coincidence with the boundaries of shires, perhaps even with underlying 'tribal' regions (Figure 2). Essex, named after the territory of the East Saxons, is ringed by three here-places, one each for the neighbouring shires of Suffolk, Cambridgeshire and Hertfordshire. Only its border with Middlesex is lacking a named site, a fact which might anyway reflect the complex political relationships that existed between these districts, particularly in the seventh and eighth centuries. ${ }^{104}$ In that case the location of Harefield $(\mathrm{Mx})$ close to the meeting of Hertfordshire, Buckinghamshire and Middlesex may be significant. Other sites give the impression of being centrally placed between groups sharing a political identity. Thetford (19) lies close to the boundary of the South and North Folk of the former kingdom of the East Angles; Harlow Hill (2), lies close to the River Tyne, and therefore near that of the Bernicians and Deirans. ${ }^{105}$ Clearly this is not straightforward liminality, for location at these boundaries actually endows the sites with an element of centrality. They sit on the borders between shires or possibly semi-autonomous regions within larger kingdoms or overlordships. This kind of internal liminality is shared by the places of muster named in narrative sources; the (likely) locations of Ecgbrihtesstan and Iglea (Iley Oak), two mustering points on Alfred's march to Edington, were near to shire boundaries, ${ }^{106}$ and Wilfaræsdun must have been close to Gatherley Moor, towards the border of Durham and the North Riding of Yorkshire. It is also echoed at a local level in the frequent positioning of hundred meetingplaces on parish boundaries. ${ }^{107}$

Most of the correlations with boundaries fall on shires which only make their appearance as administrative districts in the tenth and eleventh centuries; their interpretation depends to some extent on our evaluation of the antiquity of the boundaries that underlie shire geography. ${ }^{108}$ In this regard the absence of comparable sites from Wessex (where the documentary evidence for shire divisions is somewhat earlier) is very striking. South of the Thames, the here names discussed here are rare, and neither they nor fyrd names have close correlation with the convergence of such major boundaries. The impression is that the hereand related names represent the focal points either of a formal system imposed from above (i.e. under West Saxon jurisdiction), perhaps at the same time as the formal rearrangement of the northern shires; or of a midland, East Anglian and northern system not adopted in Wessex and perhaps greatly altered during the West Saxon expansion. In any event, we should

\footnotetext{
${ }^{103}$ Baker, 'The Language of Anglo-Saxon Defence', pp. 75-84.

${ }^{104}$ Cf. K. Bailey, 'The Middle Saxons', Origins of Anglo-Saxon Kingdoms, ed. Bassett, pp. 108-22.

105 According to Richard of Hexham, in the twelfth century, the boundary of Deira and Bernicia was the River Tyne (J. Raine, The Priory of Hexham 2 vols. (Durham, 1864-5), I, p. 20); however, D. Rollason, Northumbria, 500-1066 (Cambridge, 2003), p. 44, believes it more likely to have been the River Tees.

${ }^{106}$ Peddie, Alfred Warrior King, pp. 135-42.

107 A. Pantos, '"On the Edge of Things": the Boundary Location of Anglo-Saxon Assembly Sites', ASSAH 12 (2003), 38-49.

${ }^{108}$ Bassett, 'Administrative Landscape'.
} 
acknowledge the probability that other here names once existed that have since been lost, but the location of four such sites (five if Harwich is included) at intervals along the East Saxon/Middle Saxon frontier-effectively the West Saxon frontier for much of the ninth century-is perhaps telling.

As part of this pattern, the association of several sites $(3,10,13,15)$ with the junction of three neighbouring shires is also noteworthy, particularly in light of the Chronicle account of Alfred's muster at Egbert's Stone. ${ }^{109}$ Various locations have been considered for the site of Egbert's Stone, ${ }^{110}$ and all of them cluster close to the intersection of the shire boundaries of Wiltshire, Somerset, and Dorset. The Chronicle details earlier troop movements involving the men of more than one shire, in 860 (Berkshire and Hampshire) and 845 (Somerset and Dorset), ${ }^{111}$ and it is probable that these mobilisations similarly required a predetermined assembly place close to the boundaries of neighbouring shires. ${ }^{112}$ This class of place-names may therefore commemorate a stratum of mustering sites superior to those associated with hundreds and wapentakes, whether they originally belonged to the same chronological phase or not. This would explain why they so seldom appear in hundredal nomenclature. We might think of them as a West Saxon innovation, later rolled out as a formal system into previously Mercian territories, or as the remnants of an earlier system of large-scale musters, found across Mercia, East Anglia and Northumbria, on top of which a more regular and localised system of assemblies was later superimposed. The adoption of a unified nomenclature for these sites outside Wessex may favour imposition from above, based on a West Saxon model.

Neither interpretation can satisfactorily explain the location of all here-places. A case could be made for Harville next to Wye (12) lying on the edge of a core eastern Kentish kingdom, but this had certainly expanded further westwards by the sixth century. ${ }^{113}$ More

\footnotetext{
${ }^{109}$ I.e. the folk living west of Southampton Water, A. P. Smyth, The Medieval Life of King Alfred the Great (Basingstoke, 2002), p. 227. ASC 878.

${ }^{110}$ The likely locations are discussed by Peddie, Alfred Warrior King, pp. 135-42: Alfred's Tower (on Kingsettle Hill); Coombe St; Willoughby Hedge; Kingston Deverill. It is clear from the Chronicle entry that Egbert's Stone was east of the Selwood Forest and given subsequent events is likely to have been somewhere directly between Chippenham and Athelney. According to Abels, Alfred the Great, p. 161, the Egbert's Stone assembly was timed to coincide with Whitsuntide. This would have provided a clear and easily remembered meeting time for the fyrd of the three shires. He also argues that it is likely to have been undefended, thereby accounting for Alfred's short (one night) camp at the meeting place. Furthermore, Peddie, Alfred Warrior King, p. 135, argues that inter-shire rallying points would need to have been easily accessible and close to shire boundaries, given that such assemblies would have significantly weakened local military capabilities.

Access to communications appears to be the most significant issue underlying the location of Egbert's Stone. Peddie further argues that proximity to shire boundaries is likely to have been an issue. He suggests that shire fyrds would have stayed within their own territories until the last minute, only moving on to Egbert's Stone on the final day. Alfred himself is likely to have avoided northern trackways, preferring the Hardway from Athelney. These arguments appear to undermine the claims of Alfred's Tower and Coombe Street as the site of Egbert's Stone, as both are located too far west, and on the boundaries of shires not supplying milita for the fyrd. G.B. Grundy, 'The Ancient Highways and Tracks of Wiltshire, Berkshire and Hampshire and the Saxon Battlefields of Wiltshire', ArchJ 75 (1918), 69-194, and A. H. Burne, The Battlefields of England (London, 1996) support the Willoughby Hedge site, which does fit these criteria. This is the crossroads of Ridgeway, the Hardway, and the Grovely Ridgeway, but is quite an exposed location, and not directly accessible to troops moving from Hampshire, Wiltshire and Somerset. Instead Peddie favours the Kingston Deverill location on grounds of communications. There is here also a tradition of stones from nearby King's Court Hill, maintained to be the location of Alfred's court.

111 ASC A 860; ASC AE 845.

112 To this class of site should perhaps also be added Scutchamer Knob: the Cwichelmeshlaew recorded in the Anglo-Saxon Chronicle entry for 1006, which is located adjacent to the Ridgeway close to the former boundary of Oxfordshire and Berkshire. This is identical with the venue of a shire assembly in 990-2 (S 1454); see M. Gelling, The Place-Names of Berkshire, 3 vols, EPNS 49-51 (Cambridge, 1973-6), II, 481-2.

${ }^{113}$ The limits of the kingdom of eastern Kent have recently been discussed by S. Brookes, 'Lathes of Kent', and T. Dickinson, C. Fern and A. Richardson, 'Early Anglo-Saxon Eastry: Archaeological Evidence and the
} 
likely, given its location on a major crossroads providing good links north-south and westeast across Kent, was that it served as an assembly place centrally located for easy access from the whole lathe of the Weowara 'people of Wye', or even for the entire shire. ${ }^{114}$ The locations of Harlow in Edingley (Nt) (8), Harford (De) (16), and Hartford (Hu) (17), are similarly central to their respective territories. It may be the size of the gatherings that took place at these sites that led to their being singled out for association with a here or bēod, in contrast to other meeting-places at which only smaller groups gathered.

The evidence for this group of place-names, such as it is, is consistent with a date just prior to the major West Saxon military reorganisation of the late ninth and early tenth centuries, and this has important implications for their interpretation. If the names belong by and large to the middle Anglo-Saxon period, they may well represent a system of mustering that existed before the establishment of the hundredal system as it appears in the late tenth and eleventh centuries. In this there is convergence between the geographical location of here places at the margins of definable 'tribal' groups and the first mentions made during the ninth century to mobilisations of tactical groups named by their shire. The case for such sites existing around the territories of the East Saxons and the Hwicce has been outlined above, and it seems not unlikely that these represent the emergency mustering places of semiautonomous districts; however, the lack of comparable here places in West Saxon and Mercian heartlands is worthy of note. The absence of these names from the major middle Anglo-Saxon kingdoms might suggest that there already existed in these areas localised systems of mustering foreshadowing that of the later hundredal system.

\section{Conclusions}

In explaining place-names of the type discussed here-appellative compounds containing elements such as OE here- the tendency has been to look for a single unifying economic or topographical characteristic shared by all examples. ${ }^{115}$ Many of the sites discussed here do share certain topographical, geographical and political likenesses, but few if any of these similarities are shared by all the sites in question. In fact, what unifies them is the implication of their names: their association with large groups of people, their reference to obvious landmarks, and their partaking in the language and landscape of assembly. The distribution of these sites also makes clear they had a relation to large territorial units, defined - at least in part-by regional and 'tribal' affiliations. It may be significant that the Scandinavian hérað or hierat, a term derived from a cognate of OE here, is applied to administrative districts. ${ }^{116}$ It is clear that places called here-hlāw could also become centres of administrative districts, but the primary sense of here 'army' suggests that a notion of the mustering of force existed from the start. As is shown above, these sites have a clear correlation with the boundaries of shires, territorial units that are most prominently associated with military forces in sources of the early ninth century. ${ }^{117}$ This too hints at a military rather than a purely judicial role for sites named here-hlāw, -ford, and -feld. This model of military infrastructure supports the belief in the existence of a more general obligation affecting all freemen occupying a region, rather than the more specific infrastructures of aristocratic warfare.

Whilst the eighth and ninth centuries provide a likely context for the emergence of such sites, it is clear that regional levies were still expected to muster in specific conditions, as was the case in 878; the spatial correlation between here- names and later shire boundaries is

Development of a District Centre in the Kingdom of Kent', ASSAH 17 (2011), 1-86. The relationships between eastern and western Kent are discussed by B. Yorke, 'Joint Kingship in Kent c. 560 to 785', AC 99 (1983), 119.

${ }^{114}$ See n. 88 .

${ }^{115}$ E.g. Torvell, 'The Significance of "Here-ford"'.

${ }^{116}$ Vigfusson, Icelandic-English Dictionary, p. 257.

${ }^{117}$ Wormald, 'Papers Preparatory to The Making of English Law', p. 197. 
again relevant. Only over the course of the tenth and eleventh centuries could this function have been superseded by a more localised network of hundred/burghal musters. The reforms of the late ninth century might be thought of as a move from use of militias to use of a fyrd not just for planned offensives, but also for reactive defensive campaigns. Such a change must have had a significant impact on the organisation of mobilisation. Under the latter system, the main centres of collection - for resources and for men, and later also for legal and administrative activity - were the strongholds or burhs. Just as importantly, armies were no longer only raised on a short-term basis, for a single engagement (or short series of engagements) or to respond to an immediate threat; instead, they could be raised with longerterm objectives in mind, a precaution against a more constant background menace of invasion, or the military arm in a long-running campaign of diplomacy, expansion and conquest. Furthermore, armies of the late ninth century and later were raised from a much wider area, so that the demand on manpower in any single district was much less, and the need for individual shire musters perhaps diminished.

The military reforms of the later ninth century must have had a significant impact on the composition of armies and their strategic performance, but it should not be assumed that earlier systems geared to the raising of armies were necessarily unwieldy. An army that mobilises only to deal with present threats and disbands again after a short campaign must require a very effective system of musters, allowing the constitution of a fighting force in the shortest time possible. If the arrangements for mobilisation became outmoded-and it is certainly not clear that they did - then it would have been because they were not geared to the new end-product of fyrd and burhs. They might have become inefficient within a drastically altered military system, but need not have done so within the system for which they originally evolved.

It is our contention that these changes can be traced in the organisation of the landscape of mobilisation, which suggests the coexistence of, on the one hand, a regularly ordered and probably centrally imposed system of assemblies that might easily have served also a military purpose; and on the other hand a number of major regional gathering sites whose placenames, location and landscape context are suggestive of use as musters for warriors. These two systems may have been contemporary, reflecting the hierarchical nature of mobilisation; or they may have been chronologically distinct, a more complex system perhaps superseding an earlier territorial one to keep pace with the changing requirements of the military. Only by adopting a multidisciplinary landscape-based approach has it been possible to identify potential elements of these systems and to suggest subtle changes in the framework of mustering sites. Further multidisciplinary examination of these and similar sites may be able to add to our understanding.

In many ways, the foregoing discussion has only scratched the surface of what is a very deep and complex subject - that of military mobilisation in Anglo-Saxon England. With a few notable exceptions, it is a subject that has been largely overlooked, at least in its landscape dynamics, by commentators on Anglo-Saxon warfare. Perhaps in the main this is due to the lack of written evidence pertaining to sites of muster. If, as seems likely, mobilisation was based on the system that evolved into the network of hundred meetingplaces recorded in Domesday Book, then there is great potential to further our understanding of it, but the evidence of place-names suggests that many other important sites of military assembly may also have existed, and these too may reward further study. This paper has demonstrated that a landscape-based approach can hope to reveal a great deal more about the 
systems of military mustering so crucial in valorising military service and underpinning the military response of early medieval war leaders. ${ }^{118}$

\section{Appendix}

OE here-hlāw

The compound here-hlāw meaning 'army mound' should have the modern reflexes Harlow and Harelaw although not all instances of these modern forms share the same origin. The phonetic development of here-hlāw would usually produce Harlow as a consequence of the normal change of er>ar, ${ }^{119}$ but this is not the only compound that could produce the modern form. Where late forms only are available, the first element might be $\mathrm{OE}$ hār 'hoar, grey', or OE *hær 'stone', both of which would form semantically plausible compounds with hlāw. Other first elements have also been suggested. For example, Harlow in Lambley, the earliest form (Hoverle 1289) suggests the generic leah 'woodland', and the first element may be hofer 'a hump, hill'; ${ }^{120}$ Harelaw in Glendale (Nb;

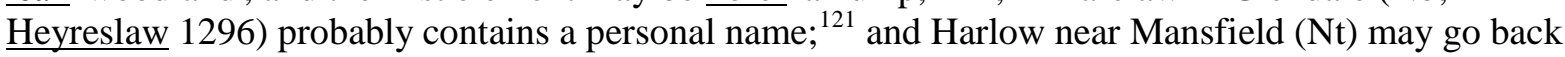
to OE hord-hlāw 'treasure mound' (Cf. Horlow Clyf 1327-77, Hurloclifes c.1450), a compound found also in Hurdlow, $\mathrm{Db}^{122}$

Harlow in Pannal, West Yorkshire (not mapped) also displays -ar- and -er- spellings, ${ }^{123}$ but not a simple change er>ar, rather an interchange of forms. It is generally taken to be a compound of OE hār 'grey' and hlāw; ${ }^{124}$ although Smith and Watts both offer the alternative *hær 'stone'. The idea that this place-name formed the first element of the neighbouring name Harrogate was dismissed by Smith, ${ }^{125}$ who derives the latter name from OScand horg 'a heap of stones, a cairn' and gata 'road', hence 'road to the cairn'. In the absence of any trace of a cairn at Harrogate, the possibility that the name Harrogate refers to the feature named Harlow should not be ruled out, especially if the first element of Harlow is taken to be $\mathrm{OE}$ *hær rather than hār. In this way, the heap of stones referred to in the wholly OScand name Harrogate might well have been the same heap named 'stone mound' by Old English speakers. A first element *hær would also seem to make better sense of the interchange between -ar- and -er- in the early forms; $\overline{\mathrm{OE}}\langle\mathfrak{x}\rangle$ being represented in ME orthography by both $\langle\mathrm{a}\rangle$ and $\langle\mathrm{e}\rangle .{ }^{126}$ The earliest -ar- form is very early to be a development from the -er- of here-hlāw.

Three instances of Hare Law or Harelaw in Northumberland and Durham $(4,5$ and 6) are taken by Mawer to contain OE hār or perhaps hara 'hare'. ${ }^{127}$ Mawer took OE hār to mean 'boundary' in these

\footnotetext{
118 This paper builds on work undertaken on two projects, Beyond the Burghal Hidage, and Landscapes of Governance, both generously funded by the Leverhulme Trust, whose support is gratefully acknowledged. Parts of the analysis were presented at the McDonald Institute, Cambridge (26 February 2011) and the Midland Viking Symposium, Leicester (28 April 2012), and discussed with colleagues on the Foundation of European Space project 2 (HAR2010-21950-C03-01) at workshops in Utstein, Norway, 23 May 2013, and Madrid, Spain 11 February 2014. We are grateful for feedback received. We would like to express particular thanks to Jayne Carroll, Ryan Lavelle and Tom Williams for reading and commenting on earlier drafts.

${ }^{119}$ R. Jordan, Handbook of Middle English Grammar: Phonology, trans. E. J. Crook (The Hague, 1974), p. 234 and cf. Oxford English Dictionay (OED), on-line, sub harbour, n.1. The normal development of OE $\underline{\text { er }}>\underline{a r}$ is a Middle English phenomenon, not evidenced in all cases before the 15th century, and it is interesting to note that Harlow Hill (7) retains er in the 14th century, while the lost Harlawe (3) shows ar already in the 13th. Harlow (1) shows signs of the change much earlier (Harlawe 1254, 1373, Harlewe 1254, Harlagh 1317), so there is no reason to question the derivation of Harlawe in Heydon on phonological grounds.

${ }^{120}$ Gover, et al., Place-Names of Nottinghamshire, p. 171; Smith, Elements, pt 1, 256.

${ }^{121}$ Mawer, Place-Names of Northumberland and Durham, pp. 101-2, suggests Hegar.

${ }^{122}$ Gover, et al., Place-Names of Nottinghamshire, p. 134; Smith, Elements, pt 1, 261; K. Cameron, The PlaceNames of Derbyshire, 3 vols., EPNS 27-9 (Cambridge, 1959), 366.

${ }^{123}$ Harelaw 1181-90, Herlawe 1219, Harlawgh 1482, Harlowe 1544, Harlo Hill 1597, Herloe 1670 (A. H.

Smith, The Place-Names of the West Riding of Yorkshire, pt 5, EPNS 34 (Cambridge, 1961), 117).

${ }^{124}$ Ekwall, Concise Oxford Dictionary, p. 221 (sub Harrogate); Smith, West Riding, pt 5, 117; Watts,

Cambridge Dictionary, p. 280.

${ }^{125}$ Smith, West Riding, pt 5, 108.

${ }^{126}$ Jordan, Handbook of Middle English, pp. 54-7; A. H. Smith, The Place-Names of the West Riding of

Yorkshirs, pt 7, EPNS 36 (Cambridge, 1962), 77.

${ }^{127}$ Mawer, Place-Names of Northumberland and Durham, pp. 101-2.
} 
instances, noting that the Pelton and Kirkharle examples were on parish boundaries, which may have influenced his interpretation of the etymology. That OE hār could mean 'boundary' was suggested by Hamper and Duignan, ${ }^{128}$ who noted the frequent occurrence of the element in charter bounds and in place-names located near to boundaries. The actual meaning of OE hār, however, is 'grey, hoar', and this could be the meaning in most instances; certain features often used as boundary markers, such as stones, are also apt to appear grey (perhaps through being overgrown with lichen), so the frequent use of the term for boundary features may be no more than coincidence. ${ }^{129}$ This being so, there is no need to interpret the Pelton and Kirkharle instances as hār names on grounds of their geographically liminal location, and there is nothing in the surviving forms that rules out derivation from here-hlāw - though of course the forms are too late for certainty either way. If the names remained transparent during the ME period, forms in -or- would more strongly point to OE hār, but such forms are not known.

More difficulty arises from the early forms of Harlow Hill in Northumberland (2). The origin was taken by Mawer to be here-hlāw and Ekwall agreed, but thought the early forms remarkable. ${ }^{130}$ Mills is also happy with this etymology. ${ }^{131}$ It must be acknowledged, however, that the range of early -ir-, -yr- and -er- forms is problematic, and led Watts to suggest a compound OE higera, higre 'magpie' and hlāw. ${ }^{132}$ While this may explain some of the earliest spellings, it does not account for the eventual -arforms, which start in the sixteenth century and could be indicative of original -er-. The development of $\underline{\mathrm{i}}<\underline{\mathrm{er}}$ does have parallels in northern England, and Mawer describes other examples, ${ }^{133}$ but none of

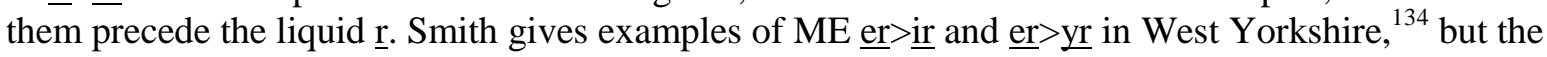
forms showing this development only go back to the fifteenth century. It is also worth noting that ME hêre was occasionally represented textually as hire. ${ }^{135}$ In the final analysis, Harlow Hill in Northumberland defies secure explanation, but the range of forms is not out of keeping with OE herehlāw, even if the dates at which those forms occur are unusually early. It is included in this discussion, but with reservations.

Many other modern instances of Harlow lack forms earlier than the nineteenth century and their etymologies must remain in doubt. Harlow in Edingley (Nt) (8), and in Mayfield (St) (9), do at least have seventeenth-century spellings and are included in the table as possible instances of here-hlāw, but their forms are not early enough for any certainty.

These and subsequent place-names are in sequence according to their map number (Figs 1 and 2). 1. Harlow (Ess), (at) Herlawe 1045 [14th], Herlaua, $-\underline{-\bar{a}} 1086 .{ }^{136}$ Watts (The Cambridge Dictionary) suggests an alternative derivation from $\mathrm{OE}$ hearg, but this is based on a supposed topographical association with a pagan temple rather than on the early spellings and can probably be set aside (see also the discussion on $\mathrm{p} . \mathrm{XX}){ }^{137}$

\footnotetext{
${ }^{128}$ W. Hamper, 'Observations on Certain Ancient Pillars of Memorial, called Hoarstones', Archaeologia 25 (1834), 24-60; W. H. Duignan, Notes on Staffordshire Place-Names (London, 1902), pp. 74-5.

${ }^{129}$ Smith, English Place-Name Elements, pt 1, 234; C. P. Biggam, Grey in Old English: an Interdisciplinary Semantic Study (London, 1998), pp. 219-25 and 231-3; P. Kitson, 'Quantifying Qualifiers in Anglo-Saxon Charter Boundaries', Folia Linguistica Historica 14.1-2 (1993), 29-82, at 37-8, Table 4 (between pp. 34 and 35), Tables 6 and 7 (between pp. 38 and 39), shows that OE hār in charter bounds occurs approximately the same number of times as other colour terms, and in general in compound with different specifics from those that qualify generics actually denoting boundaries.

${ }^{130}$ Mawer, Place-Names of Northumberland and Durham, p. 102; Ekwall, Concise Oxford Dictionary, p. 220.

${ }^{131}$ Mills, Oxford Dictionary, p. 227.

${ }^{132}$ Watts, Cambridge Dictionary, p. 280.

${ }^{133}$ Mawer, Place-Names of Northumberland and Durham, p. 256.

${ }^{134}$ Smith, English Place-Name Elements, pt 2, 292; A. H. Smith, The Place-Names of the West Riding of Yorkshire, pt 4, EPNS 33 (Cambridge, 1961), 71; Smith, Place-Names of the West Riding, pt 7, 82-3.

${ }^{135} \mathrm{cf}$. Kurath, et al., Middle English Dictionary, sub hēre n.1, although note that their examples are all from Layamon's Brut, written in a very different part of the country.

${ }^{136}$ Anglo-Saxon Wills, ed. D. Whitelock (Cambridge, 1930), 80-1; P. H. Reaney, The Place-Names of Essex, EPNS 12 (Cambridge, 1935), p. 36.

${ }^{137}$ Harlow Croft (Harlow field 1674), a field-name in Thundridge, Hertfordshire, may well be named from

Harlow in Essex, which is approximately $7.5 \mathrm{~km}$ to the south. See J. E. B. Gover, A. Mawer and F. M. Stenton, The Place-Names of Hertfordshire, EPNS 15 (Cambridge, 1938), 306.
} 
2. Harlow Hill, Ovingham (Nb), Hirlawe 1242, Hyrlawe 1245, Herlauwe 1254; Hirlawe 1278, 1329, Herlawe 1346, Herlawe 1428, Harlawe $1538 ;{ }^{138}$

3. Harlawe (1294), Heydon (Ess); ${ }^{139}$

4. Hare Law, Wolsingham (Du), Herilaw, Herlawe13th, Harelaw 1345-82;

5. Harelaw, Pelton (Du), Harelawe 1382;

6. Harelaw, Kirkharle (Nb), Harelaw $1358 ;{ }^{140}$

7. Harlow Hill, Little Maplestead (Ess), le Herlawe $14^{\text {th }} ;^{141}$

8. Harlow Field Farm, Edingley (Nt), Cf. Harlowesyke $1614 ;{ }^{142}$

9. Harlow, Mayfield (St), Cf. Harlow-greave $1686 .{ }^{14}$

OE here-feld

An alternative compound of ModE hare $(<\operatorname{ME}$ hare $<$ OE hara) and field $(<$ ME fēeld $<$ OE feld $)$ would give rise to exactly the same form, but meaning 'field frequented by hares'. For this reason, minor instances of modern Harefield (for most of which only relatively recent forms survive) are omitted from the present discussion. This leaves just three names of note, two of which seem to be fairly reliable instances of the compound, although Cullen is open to the possibility that a compound involving OE *hær 'a rock, a heap of stones' or OE hærig 'rocky' is behind Harville (Kt). ${ }^{144} \mathrm{He}$ seems, however, to prefer here-feld. Harefield in Selling (11) demands more circumspection, in view of the 1292 form. Wallenberg considered the possibility that this form was the result of some kind of 'external' influence, presumably a folk-etymological one, and compared the name with Harewell in a neighbouring parish, without coming to a firm conclusion of the origin or significance of these names. ${ }^{145}$ The 1292 form ( means a terminal objection. ${ }^{146}$

Numbering continues from the Harlow place-names above:

10. Harefield (Mx), Herefelle 1086, Herrefeld 1115, Harefeld $1223 ;{ }^{147}$

11. Harefield Farm, Selling (Kt), de Herifeud' 1240, H'defeld' $1292 ;{ }^{148}$

12. Harville Farm, Wye (Kt), Northharifeld $1271 .^{149}$

OE here-ford

Torvell analysed the topographical location of five instances of this compound, three in the west midlands, one in Devon and one in Huntingdonshire. ${ }^{150}$ To this list may, with some caution, be added a possible instance of the compound in Harraton near Chester-le-Street ( $\mathrm{Du}$ ). This would be a direct parallel to Harvington in Worcestershire (13), both being tūn names formed on an earlier place-name *Hereford, but in the Durham example the forms are less clear-cut. Mawer took the first element of

\footnotetext{
${ }^{138}$ A. Mawer, The Place-Names of Northumberland and Durham (Cambridge, 1920), 102; Ekwall, Concise Oxford Dictionary, p. 220.

${ }^{139}$ Reaney, Place-Names of Essex, 630.

${ }^{140}$ For nos. 4-6, see C. E. Jackson, The Place-Names of Durham (London, 1916), pp. 61-2; Mawer, PlaceNames of Northumberland and Durham, pp. 101-2. Another instance discussed by Mawer, in Stanhope, Scottish Borders, is omitted here.

${ }^{141}$ Reaney, Place-Names of Essex, p. 630.

${ }^{142}$ J. E. B. Gover, A. Mawer, and F. M. Stenton, The Place-Names of Nottinghamshire, EPNS 17 (Cambridge, 1940), 161

${ }^{143}$ D. Horovitz, The Place-Names of Staffordshire (Brewood, Stafford, 2005), s.n.

${ }^{144}$ P. Cullen, 'The Place-Names of the Lathes of St Augustine and Shipway, Kent', 2 vols, unpubl. PhD thesis (Univ. of Sussex, 1997), p. 41.

${ }^{145}$ Wallenberg, Place-Names of Kent, p. 295.

$146 \mathrm{cf}$. early forms for Harwich and discussion of them in Reaney, Place-Names of Essex, p. 339, and Cullen,

'Place-Names of the Lathes', 297-8.

${ }^{147}$ Gover, et al., Place-Names of Middlesex, p. 35.

${ }^{148}$ Wallenberg, Place-Names of Kent, p. 305.

149 Ibid., p. 386.

${ }^{150}$ D. Torvell, 'The Significance of "Here-ford"', JEPNS 24 (1992), 42-8.
} 
the Durham name to be a personal name Herefrið or *Herefær, but both Ekwall and Watts prefer hereford, ${ }^{151}$ Watts noting the proximity of a Roman road (although the ford in question may not have been on the line of that road).

Numbering continued from above:

13. Harvington (Wo), Hereford 799 for 802 [11th] (S:154), $\underline{\text { Herverton } 709 \text { [12th] (S:80); Hereford tun }}$ juxta Avene 964 [13th] (S:731), Herferthun 1086; ${ }^{152}$

14. Hereford (He), Herefordseir $1048 ;^{153}$

15.Little Hereford (He), Lutelonhereford 1086; ${ }^{154}$

16. Harford (De), Hereford 1086; ${ }^{15}$

17. Hartford (Hu), Hereford 1086; ${ }^{156}$

18. Harraton (Du), Hervertune c.1190, Herverton $1297 .{ }^{157}$

Other place-names mentioned in the text:

19. Thetford (Nf), peodford c. 890 ASC s.a. $870 ;^{158}$

20. Little Thetford (Ca), (æt) piutforda c.972, Liteltedford $1086 ;{ }^{159}$

21.Tetford (Li), Tesforde (sic), Tedforde $1086 ;{ }^{160}$

22. Thetford, Baston (Li), Thefford 1241-2. ${ }^{161}$

${ }^{151}$ Ekwall, Concise Oxford Dictionary, s.n.; Watts, Dictionary of County Durham Place-Names, s.n.

${ }^{152}$ A. Mawer and F. M. Stenton with F.T.S. Houghton, The Place-Names of Worcestershire, EPNS 4 (Cambridge, 1927), 134.

${ }^{153}$ A. T. Bannister, The Place-Names of Herefordshire (Cambridge, 1916), p. 93; B. Coplestone-Crow, Herefordshire Place-Names, BAR Brit. ser. 214 (Oxford, 1989), 101.

${ }^{154}$ Bannister, Place-Names of Herefordshire, p. 117.

155 J. E. B. Gover, A. Mawer, and F.M. Stenton, The Place-Names of Devon, 2 vols, EPNS 8-9 (Cambridge, 1931-2), 275.

${ }^{156}$ A. Mawer and F. M. Stenton, The Place-Names of Bedfordshire and Huntingdonshire, EPNS 3 (Cambridge, 1926), 208.

${ }^{157}$ Mawer, Place-Names of Northumberland and Durham, p. 102; V. Watts, A Dictionary of County Durham Place-Names (Nottingham, 2002), s.n.

${ }^{158}$ W. W. Skeat, The Place-Names of Suffolk (Cambridge, 1913), pp. 36-7.

${ }^{159}$ P. H. Reaney, The Place-Names of Cambridgeshire and the Isle of Ely, EPNS 19 (Cambridge, 1943), 242.

${ }^{160}$ K. Cameron, with a contribution from J. Insley, A Dictionary of Lincolnshire Place-Names (Nottingham, 1998), s.n.

${ }^{161}$ L. W. H. Payling, 'The Place-Names of Kesteven (South-West Lincolnshire)', unpubl. MA thesis (Univ. of Leeds, 1936), p. 205; M. Perrott, 'The Place-Names of the Kesteven Division of Lincolnshire', unpubl. MPhil thesis (Univ. of Nottingham, 1979), p. 395; K Cameron, with a contribution from J. Insley, A Dictionary of Lincolnshire Place-Names (Nottingham, 1998), s.n. 


\section{FIGURE CAPTIONS}

Figure 1. Distribution of place-names containing OE here (and semantically related elements) as listed in the Appendix

Figure 2. Distribution of place-names containing OE here in relation to shire boundaries as reconstructed from Domesday Book. 